Prepared in cooperation with the Idaho Water Resource Board and the Idaho Department of Water Resources

\title{
Hydrogeologic Framework of the Treasure Valley and Surrounding Area, Idaho and Oregon
}

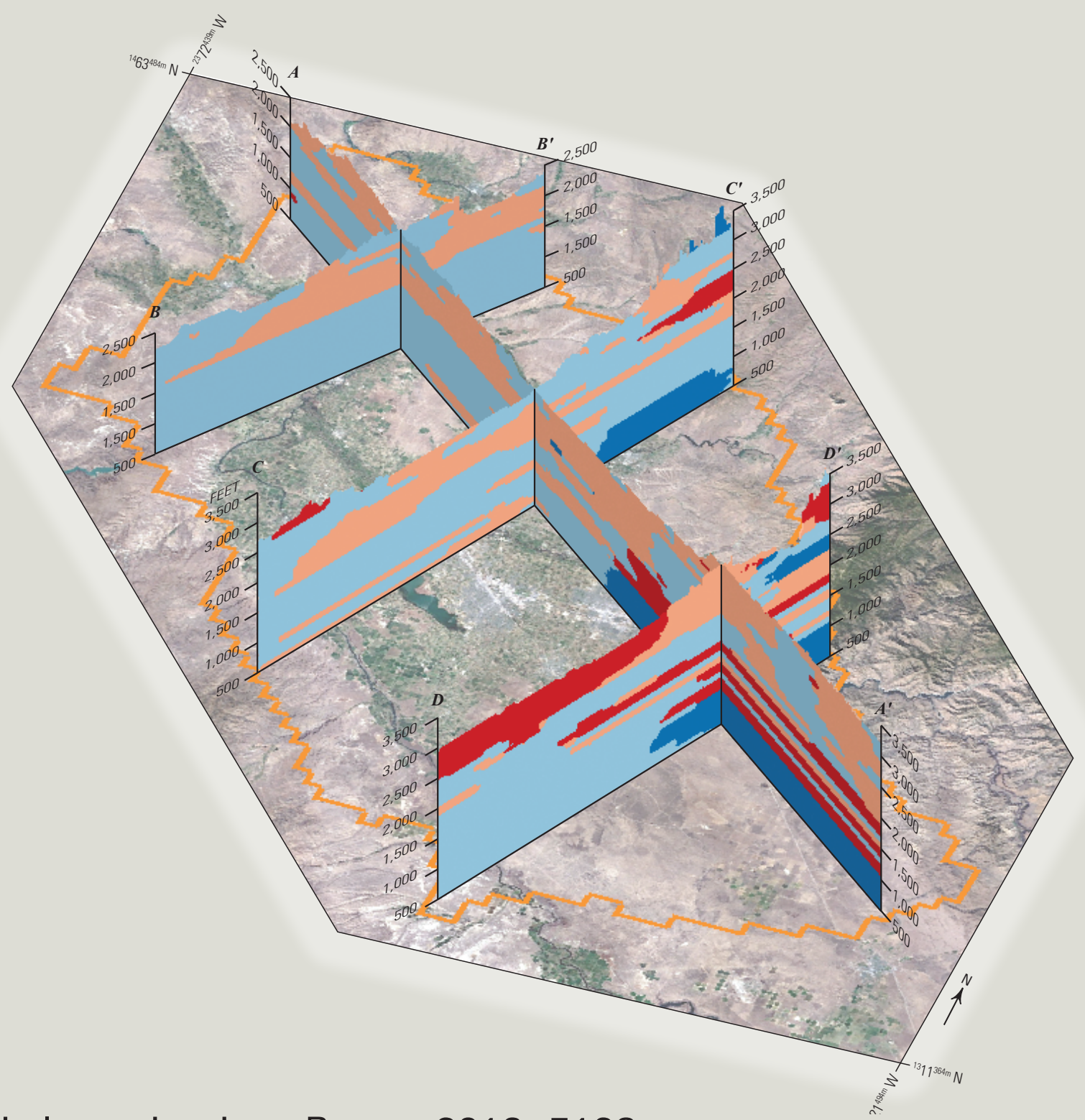

Scientific Investigations Report 2019-5138

Version 1.1, January 2020 
Cover: Perspective view of vertical cross sections through a three-dimensional hydrogeologic framework model. (Base from 2016 Google Earth imagery. Coordinate system: Idaho Transverse Mercator, North American Datum of 1983. North American Vertical Datum of 1988.) 


\section{Hydrogeologic Framework of the Treasure Valley and Surrounding Area, Idaho and Oregon}

By James R. Bartolino

Prepared in cooperation with the Idaho Water Resource Board and the Idaho Department of Water Resources

Scientific Investigations Report 2019-5138

Version 1.1, January 2020 


\title{
U.S. Department of the Interior \\ DAVID BERNHARDT, Secretary
}

\author{
U.S. Geological Survey \\ James F. Reilly, Director
}

\author{
U.S. Geological Survey, Reston, Virginia: 2020 \\ First release: 2019 \\ Revised: January 2020 (ver. 1.1)
}

\author{
For more information on the USGS - the Federal source for science about the Earth, its natural and living resources, \\ natural hazards, and the environment—visit https://www.usgs.gov or call 1-888-ASK-USGS. \\ For an overview of USGS information products, including maps, imagery, and publications, visit \\ https://store.usgs.gov/. \\ Any use of trade, firm, or product names is for descriptive purposes only and does not imply endorsement by the U.S. \\ Government. \\ Although this information product, for the most part, is in the public domain, it also may contain copyrighted materials \\ as noted in the text. Permission to reproduce copyrighted items must be secured from the copyright owner. \\ Suggested citation: \\ Bartolino, J.R., 2019, Hydrogeologic framework of the Treasure Valley and surrounding area, Idaho and Oregon \\ (ver. 1.1, January 2020): U.S. Geological Survey Scientific Investigations Report 2019-5138, 31 p., https://doi.org/ \\ 10.3133/sir20195138. \\ Associated data for this publication: \\ Bartolino, J.R., 2020, Hydrogeologic Framework of the Treasure Valley and Surrounding Area, Idaho and Oregon: U.S. \\ Geological Survey data release, https://doi.org/10.5066/P9CACOF6. \\ ISSN 2328-0328 (online)
}




\section{Contents}

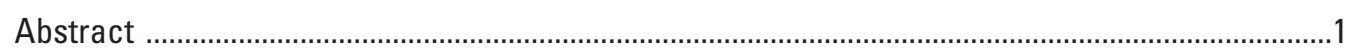

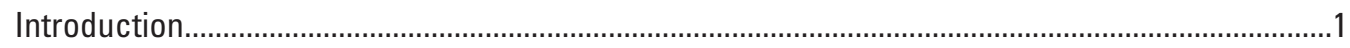

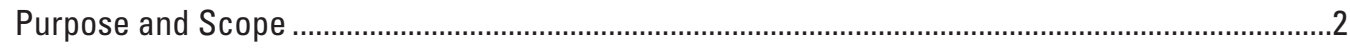

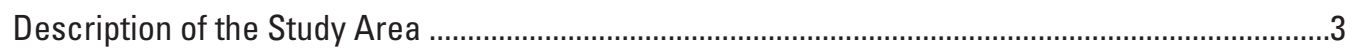

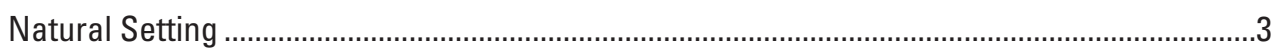

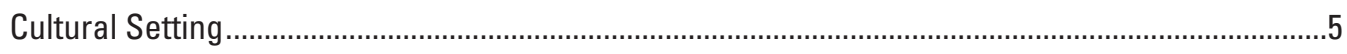

Water Resources

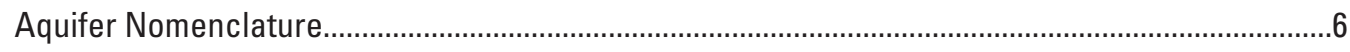

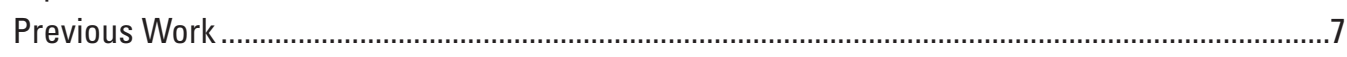

Geology

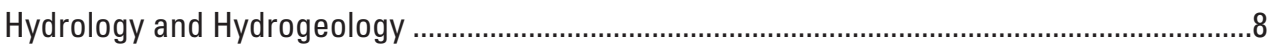

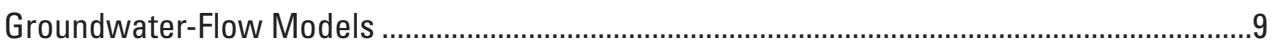

Methods

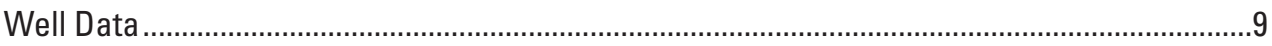

Three-Dimensional Hydrogeologic Framework Modeling.....................................................9

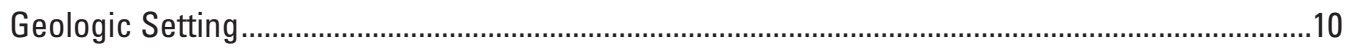

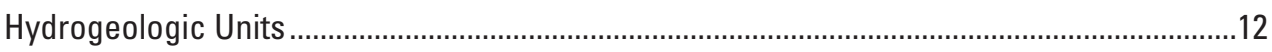

Coarse-Grained Fluvial and Alluvial Deposits...................................................................13

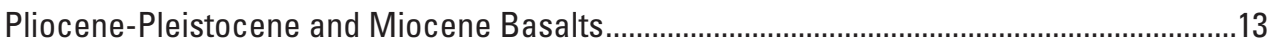

Fine-Grained Lacustrine Deposits ...................................................................................

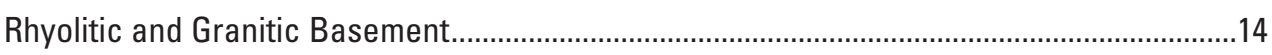

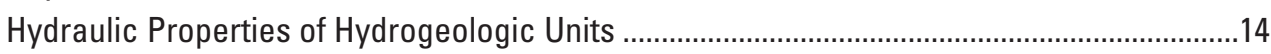

Three-Dimensional Hydrogeologic Framework Model ................................................................

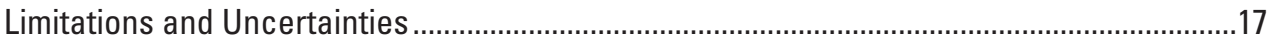

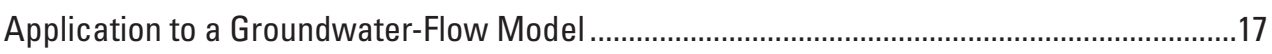

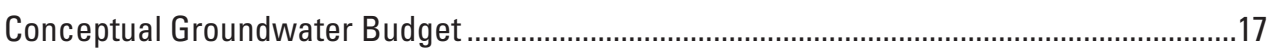

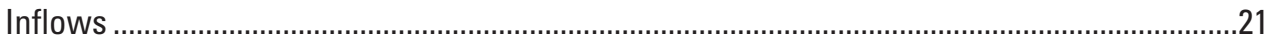

Outflows

Summary

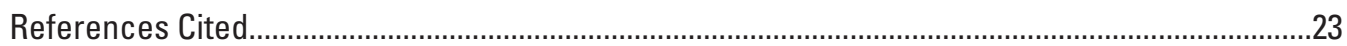




\section{Figures}

1. Map showing locations of communities, selected weather stations, and other features, western Snake River Plain, southwestern Idaho and easternmost Oregon......2

2. Map showing Palmer drought severity index for Idaho climate zone 5 (Southwestern Valleys)

3. Map showing the domains of selected groundwater models, western Snake River Plain, southwestern Idaho and easternmost Oregon.

4. Map showing wells used to generate the three-dimensional hydrogeologic framework and lines of section, western Snake River Plain, southwestern Idaho and easternmost Oregon.

5. Horizontal slices at 500-foot intervals through the three-dimensional hydrogeologic framework model.

6. Vertical cross sections through the three-dimensional hydrogeologic framework model

\section{Tables}

1. Summary of data from selected National Weather Service stations and Bureau of Reclamation AgriMet stations in and near the study area

2. Summary of western Snake River Plain aquifer nomenclature used by previous authors and the current report...

3. Geologic time scale with stratigraphic and hydrogeologic units of the western Snake River Plain, southwestern Idaho and easternmost Oregon

4. Summary of western Snake River Plain hydrogeologic units used by previous authors and the current report.

5. Published ranges for hydraulic conductivity, anisotropy, storativity, specific storage, and specific yield for selected aquifer materials and groundwater-flow models.

6. Summary of selected western Snake River Plain groundwater budgets by previous authors 


\section{Conversion Factors}

\begin{tabular}{|c|c|c|}
\hline Multiply & By & To obtain \\
\hline \multicolumn{3}{|c|}{ Length } \\
\hline inch (in.) & 2.54 & centimeter $(\mathrm{cm})$ \\
\hline foot $(\mathrm{ft})$ & 0.3048 & meter $(\mathrm{m})$ \\
\hline mile (mi) & 1.609 & kilometer (km) \\
\hline $\operatorname{meter}(\mathrm{m})$ & 3.281 & foot $(\mathrm{ft})$ \\
\hline \multicolumn{3}{|c|}{ Area } \\
\hline square mile $\left(\mathrm{mi}^{2}\right)$ & 2.590 & square kilometer $\left(\mathrm{km}^{2}\right)$ \\
\hline \multicolumn{3}{|c|}{ Flow rate } \\
\hline acre-foot per year (acre-ft/yr) & 1,233 & cubic meter per year $\left(\mathrm{m}^{3} / \mathrm{yr}\right)$ \\
\hline \multicolumn{3}{|c|}{ Specific capacity } \\
\hline $\begin{array}{l}\text { gallon per minute per foot } \\
[(\mathrm{gal} / \mathrm{min}) / \mathrm{ft})]\end{array}$ & 0.2070 & $\begin{array}{l}\text { liter per second per meter } \\
{[(\mathrm{L} / \mathrm{s}) / \mathrm{m}]}\end{array}$ \\
\hline \multicolumn{3}{|c|}{ Hydraulic conductivity } \\
\hline foot per day (ft/d) & 0.3048 & meter per day $(\mathrm{m} / \mathrm{d})$ \\
\hline
\end{tabular}

Temperature in degrees Fahrenheit $\left({ }^{\circ} \mathrm{F}\right)$ may be converted to degrees Celsius $\left({ }^{\circ} \mathrm{C}\right)$ as follows:

$$
{ }^{\circ} \mathrm{C}=\left({ }^{\circ} \mathrm{F}-32\right) / 1.8
$$

\section{Datum}

Vertical coordinate information is referenced to the North American Vertical Datum of 1988 (NAVD 88).

Horizontal coordinate information is referenced to the North American Datum of 1983 (NAD 83). Altitude, as used in this report, refers to distance above the vertical datum.

\section{Abbreviations}
DEM Digital elevation model
ESRP Eastern Snake River Plain
IDWR Idaho Department of Water Resources
IGS Idaho Geological Survey
NWS National Weather Service
PDSI Palmer Drought Severity Index
RASA Regional Aquifer-System Analysis
TVHP Treasure Valley Hydrologic project
USGS U.S. Geological Survey
WSRP Western Snake River Plain

3D HFM Three-dimensional hydrogeologic framework model 



\title{
Hydrogeologic Framework of the Treasure Valley and Surrounding Area, Idaho and Oregon
}

\author{
By James R. Bartolino
}

\section{Abstract}

Most of the population of the Treasure Valley and the surrounding area of southwestern Idaho and easternmost Oregon depends on groundwater for domestic supply, either from domestic or municipal-supply wells. As of 2017, 41 percent of Idaho's population was concentrated in Idaho's portion of the Treasure Valley, and current and projected rapid population growth in the area has caused concern about the long-term sustainability of the groundwater resource. In 2016, the U.S. Geological Survey, in cooperation with the Idaho Water Resource Board and the Idaho Department of Water Resources, began a project to construct a numerical groundwater-flow model of the westernmost western Snake River Plain (WSRP) aquifer system. As part of this project, a three-dimensional hydrogeologic framework model (3D HFM) of the aquifer system was generated, primarily from lithologic data compiled from 291 well-driller reports.

Four major hydrogeologic units are shown in the 3D HFM: Coarse-grained fluvial and alluvial deposits, Pliocene-Pleistocene and Miocene basalts, fine-grained lacustrine deposits, and granitic and rhyolitic bedrock. Generally, the 3D HFM is in agreement with the geologic history of the WSRP and hydrogeologic frameworks developed by previous authors. The resolution (voxel size) of the 3D HFM is sufficient for the construction of a regional groundwater-flow model.

The major components of inflow (or recharge) to the WSRP aquifer system are seepage from irrigation canals, direct infiltration from precipitation and excess irrigation water, seepage from the Boise and Payette Rivers and Lake Lowell, and subsurface inflow from adjoining uplands. The major components of outflow (or discharge) from the aquifer system are discharge to surface water (rivers, agricultural drains, and streams), groundwater pumping, and direct evapotranspiration from groundwater.

\section{Introduction}

The Treasure Valley is "the agricultural area that stretches west from Boise into Oregon" (U.S. Board on Geographic Names, 2019), although it is commonly referred to as "the lower Boise River watershed" or "the Boise River drainage basin downstream of Lucky Peak Lake" (fig. 1); it lies within the westernmost part of the western Snake River Plain (WSRP). Except for the 30 percent of Boise's municipal supply taken from the Boise River (SUEZ North America, 2019), groundwater withdrawals provide most of the domestic and municipal water in the valley and surrounding area.

SPF Water Engineering (2016) estimated that the population of the Treasure Valley will increase to about 1.6 million by 2065 , resulting in a corresponding increase in domestic, commercial, municipal, and industrial water demand. To address this anticipated demand for water, the Idaho Senate passed Concurrent Resolution 137, which includes a request to "develop a ground water model, with all necessary measurement networks" for the Treasure Valley (Idaho Senate Resources and Environment Committee, 2016, p. 2). In 2016, the U.S. Geological Survey (USGS), in cooperation with the Idaho Water Resource Board and the Idaho Department of Water Resources (IDWR), began a project to collect additional drain discharge data (in the form of 10 new streamgages and three streamflow-measurement sites) and create a groundwater-flow model of the Treasure Valley and surrounding area.

The study area used in this report is taken as the extent of a groundwater-flow model by Johnson (2013) (fig. 1). This area includes the westernmost part of the WSRP and is bounded by the Snake River to the south and west, part of the lower Payette River drainage basin downstream of Black Canyon Reservoir to the north, and a groundwater divide near the Ada-Elmore County line to the east (fig. 1). 


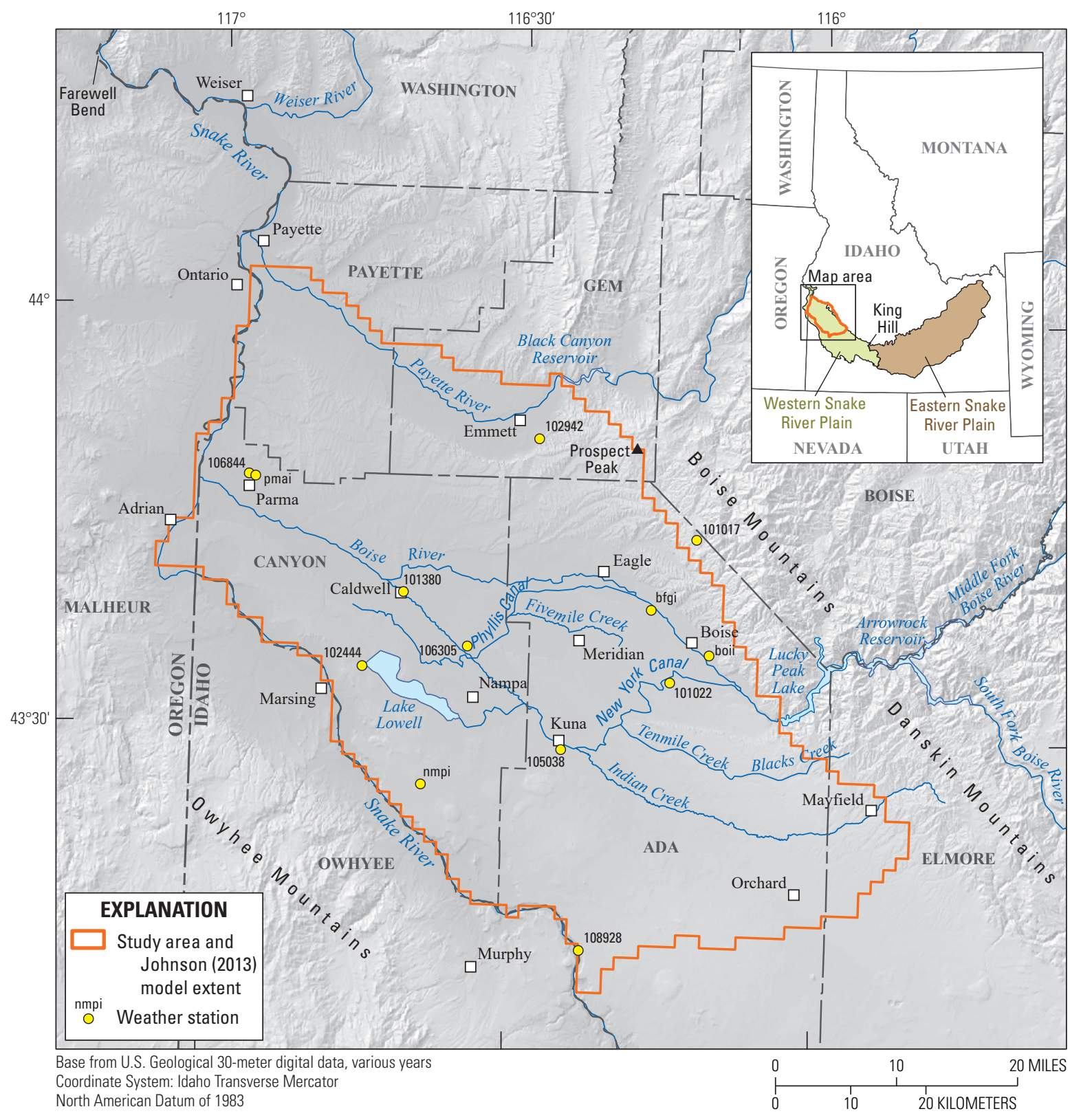

Figure 1. Locations of communities, selected weather stations, and other features, western Snake River Plain, southwestern Idaho and easternmost Oregon.

\section{Purpose and Scope}

This report describes the development of an updated hydrogeologic framework for the westernmost part of the WSRP aquifer system that is represented in a three-dimensional hydrogeologic framework model (3D HFM) and includes a conceptual groundwater budget. This updated framework is primarily based upon the review of well-driller reports, but also upon geologic maps, geophysical data, and previous studies. The 3D HFM is intended for use in the development of a groundwater-flow model of the westernmost part of the WSRP aquifer system for 1986-2015 and is available in a companion data release to this report https://doi.org/10.5066/P9CAC0F6. 


\section{Description of the Study Area}

\section{Natural Setting}

The study area encompasses about 1,820 square miles $\left(\mathrm{mi}^{2}\right)$ and is located in the WSRP of southwestern Idaho and easternmost Oregon (fig. 1). It consists of an undulating plain that slopes generally from southeast to northwest; the northern part is separated by an east-west line of uplands that forms the interfluve between the Boise River watershed to the south and the Payette River watershed to the north. The WSRP is bounded by the Boise and Danskin Mountains to the north (altitude as high as 10,000 feet [ft]) and the Owyhee Mountains to the south (altitude as high as $8,400 \mathrm{ft}$ ). In the study area, altitude ranges from about 4,810 ft at Prospect Peak along the north-central boundary to 2,140 ft on the Snake River to the northwest.

The study area is drained by three major rivers: the Snake River to the south and west, the Boise River in the central portion, and the Payette River to the north. About 66 percent of the study area lies within the Boise River watershed, 23 percent within the Payette River watershed, and 11 percent drains directly to the Snake River.

The climate of the study area is categorized into three Köppen climate classifications. Roughly east to west the classifications are hemiboreal climates with warm and dry summers (Dsb), continental climates with hot and dry summers (Dsa), and semiarid cold steppe climates (BSk) (Lutgens and Tarbuck, 1982; Idaho State Climate Services, 2011).

Eight National Weather Service (NWS) stations and four Bureau of Reclamation AgriMet stations are located within or adjacent to the study area and provide data for some or all of the groundwater-flow model period of 1986-2015 (fig. 1; table 1) (National Oceanic and Atmospheric Administration, 2019; Bureau of Reclamation, 2019). For all of the NWS stations, the coldest month is January and the warmest month is July (table 1$)$. The mean last-freeze $\left(32.5^{\circ} \mathrm{F}\right)$ date ranges from April 21 to May 22, and the mean first-freeze $\left(32.5^{\circ} \mathrm{F}\right)$ date ranges from September 23 to October 24. Mean annual precipitation, which combines rainfall and snowfall (as snow water equivalent), ranges from 7.8 to 19 inches (in.), and mean annual snowfall ranges from 3.9 to 55 in. July and August are typically the driest months; December and January are typically the wettest. The greatest monthly mean snow depth is 1 in. or less (except at the Parma Experiment Station weather station with 2 in.) and typically occurs in January (Western Regional Climate Center, 2019).

Although drought can be defined in many different ways (meteorological, hydrological, or agricultural), one commonly used measure is the Palmer Drought Severity Index (PDSI), a measure of long-term drought that uses precipitation, temperature, soil moisture, and other factors. The index accounts for long-term trends to define wet and dry periods, thus limiting its use in the most recent record. The PDSI uses zero as normal, negative numbers to represent drought, and positive numbers to represent above-normal precipitation. The National Climatic Data Center calculates the PDSI (and other drought indices) for states by climate division; except for Oregon, all of the study area is within Idaho climate zone 5 (or Southwestern Valleys division) (National Climatic Data Center, 2019). The PDSI for Idaho climate zone 5 from January 1900 through December 2018 is shown in figure 2. The 360 months between January 1986 and December 2015 (period of record for the groundwater-flow model) are characterized by 3 periods of drier than normal conditions for at least 50 consecutive months and one period of wetter than normal conditions for 53 consecutive months. Of the 360 months, 15 had PDSI values less than -0.5 and greater than or equal to -1 , indicating drier than normal conditions; 227 experienced mild to extreme drought conditions (less than -1); 99 months experienced slightly to very wet conditions (greater than 0.5 ), leaving only 19 months in the normal range. The range of PDSI values is 5.61 (July 1998) to -6.34 (July 1992). The average PDSI value for these 360 months is -1.18 .

A comparison of the three periods of drier than normal conditions between January 1986 and December 2015 to PDSI values for the entire 20th century shows that the 1986-2015 period is matched in duration and severity by only the well-known drought of the 1930s (fig. 2). One period during the 1930s drought consisted of 62 months of drier than normal conditions.

Three level-IV ecoregions (areas of generally similar ecosystems) occur over the approximately $2,700 \mathrm{ft}$ of relief in the study area. Roughly from north to south, these ecoregions are: Treasure Valley (12a), Unwooded Alkaline Foothills (12j), and Mountain Home Uplands (12h) (McGrath and others, 2002). 


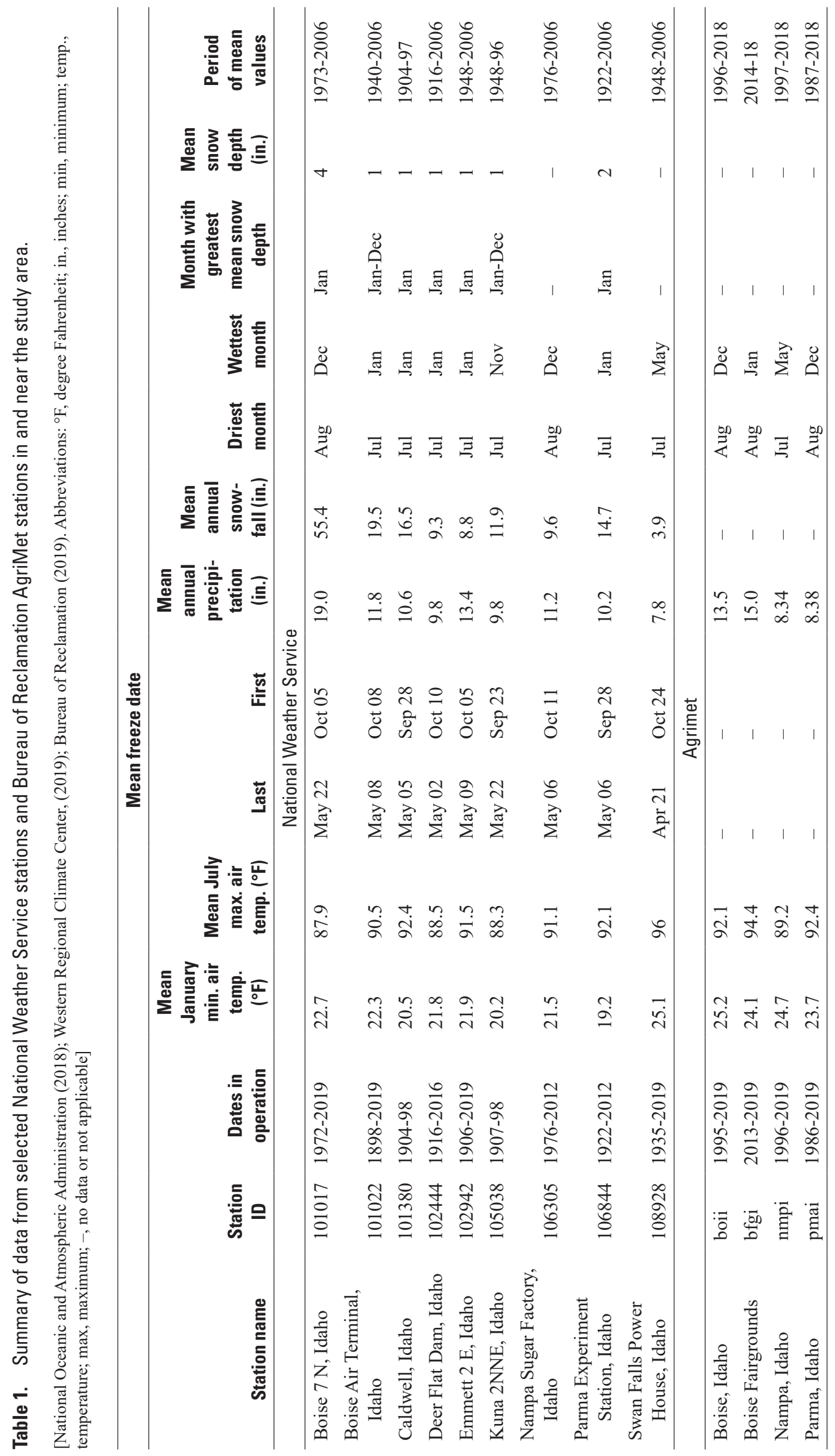




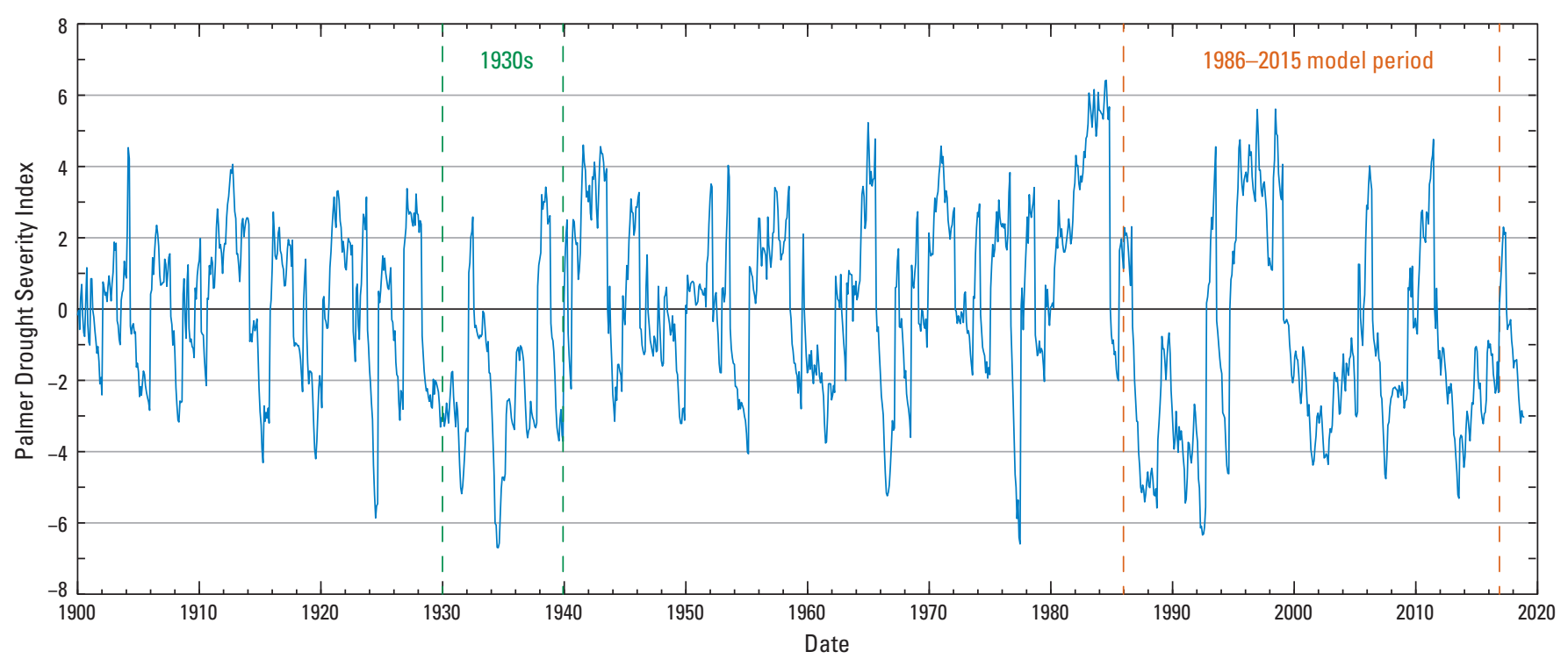

$\begin{array}{lllll}\text { Palmer Drought Severity Index value } & & & \\ -4 \text { or less Extreme drought } & -1 \text { to }-0.5 & \text { Incipient dry spell } & 2 \text { to } 3 & \text { Moderately wet } \\ -4 \text { to }-3 & \text { Severe drought } & -0.5 \text { to } 0.5 \text { Near normal } & 3 \text { to } 4 & \text { Very wet } \\ -3 \text { to }-2 & \text { Moderate drought } & 0.5 \text { to } 1 \quad \text { Incipient wet spell } & 4 \text { or more Extremely wet } \\ -2 \text { to }-1 & \text { Mild drought } & 1 \text { to } 2 \quad \text { Slightly wet } & \end{array}$

Figure 2. Palmer drought severity index for Idaho climate zone 5 (Southwestern Valleys).

\section{Cultural Setting}

Land ownership in the study area is mostly private, with about 22 percent of the total area owned by the Federal Government. Most of this Federal land is managed by the Bureau of Land Management (U.S. Geological Survey, 2019c).

All or parts of Ada, Canyon, Elmore, Gem, and Payette Counties in Idaho and Malheur County, Oregon, lie in the study area. In 2017, the estimated population of the study area was about 702,000 (excluding Elmore and Malheur Counties because they contain few people in the study area, and the Sweet and Payette census county divisions of Gem and Payette Counties, respectively, because they lie largely outside the study area) (U.S. Census Bureau, 2019). This represents about 41 percent of the total population of Idaho (U.S. Census Bureau, 2019). By contrast, the population of the study area in 1990 was about 313,000 ; thus, the population more than doubled between 1990 and 2017 (U.S. Census Bureau, 2019). The study area contains the three largest and sixth largest cities in Idaho: Boise, Meridian, Nampa, and Caldwell, respectively (fig. 1).

Agriculture and related industries (including food processing) have historically been the largest employers in southwestern Idaho. In recent years, however, the largest employers are the health care and social assistance sectors, followed by retail, manufacturing, hospitality, and government (Idaho Department of Labor, 2018)

\section{Water Resources}

Three main rivers drain the study area, all tributary to the Columbia River: the Snake River and its tributaries, and the Boise and Payette Rivers (fig. 1). The drainage area of each where they enter the study area is about $42,000,2,700$, and 2,700 $\mathrm{mi}^{2}$, respectively (U.S. Geological Survey, 2019b). In the study area, several small perennial and ephemeral streams drain to the three main rivers. Numerous diversions from the Boise and Payette Rivers (and to a lesser extent the Snake River) feed a large network of canals that are typically operated during the mid-April through late-September irrigation season. Development of this irrigation network started in 1863 and continued into the early twentieth century (Stacy, 1993; Stevens, undated a, b). This network included the construction of off-stream reservoirs such as Lake Lowell (fig. 1). By 1904, landowners in the Nampa-Caldwell area began reporting water-logged lands as a result of water infiltration from canals and applied irrigation water (Stevens, undated a, b) (fig. 1). This led to the construction of an extensive network of agricultural drains in the study area.

The WSRP aquifer system is the source of water for wells in the study area that provide groundwater for irrigation, domestic and municipal supply, industry, livestock, and geothermal heating. The aquifer system can broadly be conceptualized as having three parts: a shallow water-table aquifer; a complex, deep, underlying aquifer under confined conditions; and a lowermost confined geothermal aquifer. Groundwater in the shallow aquifer and surface water are 
closely connected, and groundwater flow is generally from topographic highs to rivers and drains. Generally, depth to groundwater varies from land surface or above to depths of more than $800 \mathrm{ft}$ below land surface. Groundwater levels in the shallow water-table aquifer are typically lowest before the beginning of irrigation season and highest near the end of irrigation season when surface-water diversions cease; in the middle aquifer this pattern is typically reversed. Water levels in the geothermal aquifer are typically lowest at the end of winter and highest in the late summer or early autumn. In parts of the study area, nonthermal springs provide water for domestic-water supply and irrigation.

The use of geothermal water for heating in the WSRP began in 1891 with the completion of wells in northeast Boise; currently (2019), there are four geothermal-heating districts in and near downtown Boise. The IDWR classifies wells that produce water between 85 and $212^{\circ} \mathrm{F}$ as low-temperature geothermal wells; those that produce water above $212^{\circ} \mathrm{F}$ are classified as geothermal-resource wells (Idaho Department of Water Resources, 2019a). In 1987 the IDWR designated the Boise Front Low-Temperature Geothermal Resource Groundwater Management Area in order to manage this resource.

\section{Aquifer Nomenclature}

Previous authors have used a variety of names for the water-bearing rocks that underlie all or part of the current study area. In addition to the varying names, both the hierarchical terms "aquifer" and "aquifer system" have been used. An aquifer is "a rock unit that will yield water in a usable quantity to a well or spring" (Heath, 1983); "an aquifer system is two or more aquifers that are separated (at least locally) by impermeable rock units but function together as an aquifer with regional extent" (Bartolino and Cole, 2002).

Aquifer names have included references to Boise such as the "Boise Valley aquifer" (Lindgren, 1982) and the "Boise aquifer system" (Squires and others, 1992) (table 2). The USGS Regional Aquifer-System Analysis (RASA) program defined the "Snake River Plain regional aquifer system" encompassing the entire Snake River Plain; it was divided into eastern (ESRP) and western (WSRP) parts near the junction of Salmon Falls Creek and the Snake River because of dissimilar geology and little to no subsurface hydraulic connection between the two parts (fig. 3) (Whitehead, 1992). Newton (1991) constructed a groundwater-flow model of the WSRP regional aquifer system that extended from the junction of Salmon Falls Creek and the Snake River to the junction of the Payette and the Snake Rivers (fig. 3). Cosgrove (2010) used "western Snake Plain aquifer" in an evaluation of groundwater-flow models of the area. Publications from the IDWR Treasure Valley Hydrologic Project (TVHP) used "Treasure Valley aquifer system" (Petrich, 2004b), as did a groundwater-flow model that extended into the Payette River drainage (Johnson, 2013). This list is not comprehensive; other names refer to units within the aquifer by their relative position such as upper and lower or by geologic unit name such as Idaho Group and Pierce Gulch Sand.

Because the study area includes parts of the Boise and Payette River basins and lies within the WSRP defined by Newton (1991) and Whitehead, (1986, 1992) "western Snake River Plain aquifer system" is used in this report.

Table 2. Summary of western Snake River Plain aquifer nomenclature used by previous authors and the current report.

\begin{tabular}{ll}
\hline \multicolumn{1}{c}{ Aquifer name } & \multicolumn{1}{c}{ Reference } \\
\hline Boise Valley aquifer & Lindgren (1982) \\
Snake River Plain regional aquifer system & Newton (1991) \\
Boise aquifer system & Squires and others (1992) \\
Treasure Valley aquifer system & Petrich (2004) \\
Western Snake Plain aquifer & Cosgrove (2010) \\
Treasure Valley aquifer & Johnson (2013) \\
Western Snake River Plain aquifer system & Current report \\
\hline
\end{tabular}




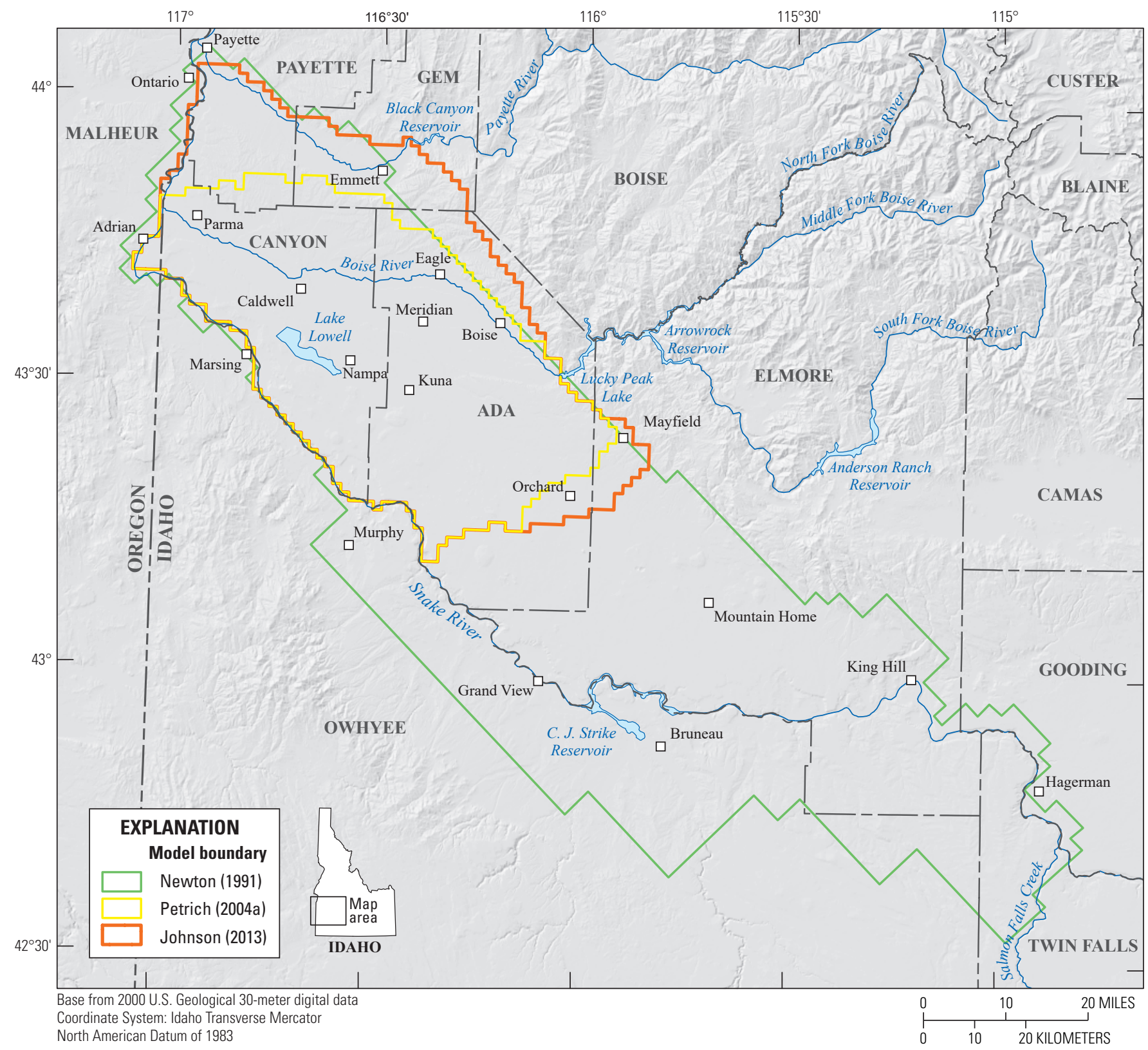

Figure 3. The domains of selected groundwater models, western Snake River Plain, southwestern Idaho and easternmost Oregon.

\section{Previous Work}

Hundreds of published and unpublished reports on various aspects of the geology and hydrology of the WSRP have been prepared by government agencies, universities, and consultants. It is beyond the scope of the current report to discuss all of these previous works; the following discussion touches on some of the reports deemed most relevant in preparing the 3D HFM described in this report.

\section{Geology}

The earliest descriptions of the geology of the WSRP were associated with the second John C. Frémont expedition (1843-44), followed by the Fortieth Parallel Survey of Clarence King (1867-72) (Malde and Powers, 1962).

Lindgren (1898) and Lindgren and Drake (1904a, 1904b) described the Boise, Nampa, and Silver City 30-minute geologic quadrangles, respectively. They included descriptions of general geography, stratigraphy, mineral resources, soils, and groundwater resources. Russell (1902, 1903a,1903b) reported on the geology and water resources of the WSRP. 
Savage described the geology and mineral resources of Ada and Canyon Counties (1958) and of Gem and Payette Counties (1961). Malde and Powers (1962) refined the upper Cenozoic stratigraphy of the WSRP, thus clarifying or establishing many of the geologic unit names currently (2019) in use. Because many stratigraphic units are exposed only along the margins of the WSRP, correlation is difficult, and a number of "local formations and informal stratigraphic units" have been used in geologic mapping in the northern part of the plain (Othberg, 1994). These units were originated by Wood and Anderson (1981), Wood and Burnham (1983), Othberg and Burnham (1990), and Burnham and Wood (1992); the resulting unit names were used by subsequent authors including Wood and Clemens (2002), Wood (1994, 2004), and Squires and others (2007). Malde (1991) and Wood and Clemens (2002) described the geologic development and evolution of the WSRP. Othberg (1994) addressed the geology and geomorphology of the Boise Valley with an emphasis on Pleistocene stream terraces of the Boise River.

A number of geologic maps of parts of the WSRP have been compiled and published, including Othberg and Burnham (1990), Othberg and others (1990), Othberg and Stanford (1990, 1992), Ferns and others (1993), Bonnichsen and Godchaux (2006a, 2006b), Phillips and others (2012), Lewis and others (2016), Feeney and others (2018), and a number of unpublished student theses. The most recent statewide geologic map of Idaho compiled by Lewis and others (2012) included some areas not covered by larger scale maps.

\section{Hydrology and Hydrogeology}

Early reports that mention groundwater in parts of the WSRP include Lindgren (1898), Lindgren and Drake (1904a, 1904b), and Russell (1902, 1903a,1903b). Mundorff and others (1964) described groundwater occurrence and conditions for the entire Snake River Plain. The USGS Snake River Plain RASA program described various aspects of the hydrogeology of the eastern and western Snake River Plain in several publications. RASA publications for the WSRP include depth to water maps (1980 conditions) (Lindholm and others, 1982; 1988), a water budget (Kjelstrom, 1995), a geohydrologic framework (Whitehead, 1986, 1992), a map of irrigated lands and land use (1980 conditions) (Lindholm and Goodell, 1986), and steady-state and transient MODFLOW models (Newton, 1991). Following the RASA, Maupin (1991) used 1980-88 data to construct a composite depth-to-water map for the WSRP, including much of the study area. The TVHP, led by the IDWR in cooperation with numerous other government and private entities, characterized groundwater and surface-water resources of the Treasure Valley. Project reports included the hydrogeologic framework of Squires and others (1992), a groundwater-flow model by Petrich (2004a), and a number of other reports that are listed in Petrich (2004b).

Published accounts of groundwater occurrence and conditions for subareas of the WSRP include Deick and Ralston (1986), Baldwin and Wicherski (1994), Tesch (2013), and Bartolino and Hopkins (2016).

Residential development of varying scale and density has occurred in the upland that forms the divide between the Boise and Payette Rivers (the Boise Valley-Payette Valley interfluve). Several reports, including Baker (1991), SPF Water Engineering, LLC (2004), and Squires and others (2007), have addressed groundwater in this area. Additional supporting material including geophysics, water levels, aquifer tests, groundwater-flow models, and geochemical data are available in SPF Water Engineering, LLC (2004), and Squires and others (2007).

Groundwater budgets for major portions of the WSRP include those published by Kjelstrom (1995), Urban (2004), Schmidt and others (2008), and Sukow (2012). Additionally, the groundwater-flow models discussed in the "Groundwater-Flow Models" section of this report all have associated groundwater budgets. There are also numerous groundwater budgets for smaller areas such as those of Lindgren (1982) and Tesch (2013). Published streamflow gain/ loss studies include Kjelstrom (1995), Berenbrock (1999), and Etheridge (2013). The majority of aquifer tests performed to establish hydraulic properties of the aquifer system are found in consultants' reports such as SPF Water Engineering (2004) and Hydro Logic Inc, (2008); Petrich and Urban (2004) contains a compilation of Treasure Valley aquifer tests. A number of reports address the hydrogeology of the geothermal aquifer, including several parts of IDWR Information Bulletin 30 such as Waag and Wood (1987) and Mitchell (1981); other reports include those by Nelson and others (1980), James M. Montgomery Consulting Engineers (1982), and Wood and Burnham (1983).

Geochemical studies relating to groundwater flow and recharge include Mitchell (1981), Mayo and others (1984), Hutchings and Petrich (2002a, 2002b), Adkins and Bartolino (2003), Thoma (2008), Busbee and others (2009), Welhan (2012), and Hopkins (2013).

Stevens (undated) examined 1867 and 1875 public land surveys to characterize hydrologic conditions of the Boise River, and Five Mile, Ten Mile, and Indian Creeks, as well as construction of the drainage system necessitated by irrigation-caused waterlogging. 


\section{Groundwater-Flow Models}

Eight groundwater-flow models of all or part of the WSRP have been published with varying objectives, detail, and model extent (Cosgrove, 2010; Johnson, 2013). Three models include all or most of the current study area: those of Newton (1991), Petrich (2004a), and Johnson (2013) (fig. 3). Models by Lindgren (1982), Douglas (2007), Pacific Groundwater Group (2008a, 2008b), Schmidt (2008), and Bureau of Reclamation (2009) are of smaller areas. Cosgrove (2010) evaluated these models (excepting Johnson, 2013) including their suitability for predictive use and the relative strengths and weaknesses of each. Sukow $(2012,2016)$ addressed various aspects of the Johnson (2013) model.

\section{Methods}

\section{Well Data}

The primary sources of data for this hydrogeologic framework of the WSRP aquifer system are well-driller reports (also known as drillers' logs) maintained by the IDWR that are available through an online database of those reports (Idaho Department of Water Resources, 2019b). The IDWR database contains "most of the well-driller reports dating back to July 1987"; but because such reports were requested but not required by the IDWR prior to 1953 (Castellin and Winner, 1975), the database does not contain reports for all wells drilled in the study area. The database does include, however, reports for many wells drilled before 1987 (within the study area, the oldest well in the database with a well-driller report was drilled in 1913). Currently (2019), the database contains records for nearly 50,000 wells in and near the study area; many of these wells lack reports or accurate location information.

Petroleum and geothermal wells are typically drilled to greater depths than water wells; the former are not included in the IDWR database. The Idaho Geological Survey (IGS) maintains a database of "over one hundred fifty" petroleum and 95 permitted geothermal wells in the state (Idaho Geological Survey, 2019). Although the available data and data quality vary by well, they may include lithology and various borehole geophysical logs (within the study area, the oldest well in the database was drilled in 1907).

For the current study, well-driller reports were retrieved from the IDWR database for the study area and immediate vicinity. Well locations on the reports have historically been reported using the Public Land Survey System (PLSS) to the 160-acre, 40-acre, or 10-acre tract level, although newer reports are required to have global-positioning system (GPS) coordinates. For this study, in the absence of a more precise location, latitude and longitude were assigned to the center of the smallest assigned tract to denote the well location. Consequently, reported well locations may vary from actual locations. The quality of location and lithologic information from well-driller reports can be highly variable.

\section{Three-Dimensional Hydrogeologic Framework Modeling}

In preparation for the construction of a groundwater-flow model of the WSRP, a 3D HFM was prepared to represent the subsurface distribution and thickness of four hydrogeologic units. The primary source of data for the 3D HFM was lithologic data from a total of 291 well-driller reports (as described in the "Well Data" section). These data were then entered into Rockware Rockworks 17 ${ }^{\mathrm{TM}}$ three-dimensional modeling software. A total of 28 lithology types were defined in Rockworks $17^{\mathrm{TM}}$ based upon well-driller report descriptions; these lithology types were then assigned to one of four hydrogeologic units. Compound lithologic descriptions such as "silty clay" or "sandy shale" are common in the well-driller reports; these compound descriptions were not treated as unique lithologies because it would result in an unwieldy number of lithology types. Instead, such compound descriptors were treated as the base lithology: "silty clay" and "sandy shale" were recorded as clay and shale, respectively.

Well locations were taken from the IDWR (2017) "Wells" dataset. Well surface elevations were assigned from the USGS National Elevation Dataset 1/3 arc-second (approximately 10 meters $[\mathrm{m}]$ ) digital elevation model (DEM) (U.S. Geological Survey, 2019a).

The 3D HFM was generated of a rectangular area larger than the groundwater-flow model boundary of Johnson (2013) to incorporate additional well data in the eastern part of the area where few wells exist (fig. 4). The base of the model was chosen as $500 \mathrm{ft}$ altitude because only 15 wells had lithologic data below that depth; 11 wells had lithologic data below the vertical datum. The modeling algorithm chosen within Rockworks17 1 TM was "lateral blending" with "cylinder" smoothing; voxel size was $400-\mathrm{m}$ by $400-\mathrm{m}$ in the horizontal dimension and $50 \mathrm{ft}$ in the vertical dimension (the mixed metric and U.S. customary units are because the Idaho Transverse Mercator [NAD83] projection uses meters for horizontal location and well-driller reports use feet for depth). The surface of the model and well elevations were adjusted to a corresponding 400-m square elevation grid (corresponding to voxels) derived from the USGS National Elevation Dataset 1 arc-second (approximately $30 \mathrm{~m}$ ) DEM (U.S. Geological Survey, 2019a). The larger rectangular hydrogeologic model was then clipped to the Johnson (2013) model boundary. 


\section{Geologic Setting}

As described in the "Previous Work" section, the stratigraphic nomenclature of the WSRP is problematic for a number of reasons. First and foremost is that the stratigraphy of the basin fill is not exposed and thus may only be described by samples from a handful of deep wells and indirect geophysical methods; geologists have thus depended on exposed outcrops on the margins of the WSRP. Other problems include a number of informally named units, a lack of unit correlation between the southern and northern margins of the WSRP, and the repeated redefinition of some units. A sense of the disorder in stratigraphic nomenclature is found in Repenning and others (1995), who describe the history of some of these unit names starting with Cope (1883). Recent mapping (including age dating) by the IGS near Emmett has begun to address these issues by clarifying the relationship between some of these units and assigning ages to them (Lewis and others, 2016; Feeney and others, 2018; Wood and others, 2018). Nevertheless, many problems remain, and the current report avoids the use of stratigraphic names where possible. Where names are used, the reader is advised that some are ambiguous and may be redefined by further work. Table 3 shows geologic time and geologic history, rock units of the WSRP, and hydrogeologic units defined in the current report. Correlation between the different columns of the table should be considered approximate.

The water-bearing units of the WSRP are underlain by a variety of older rocks (table 3 ). In the northern and northeastern parts of the study area, these underlying rocks are Proterozoic and older metamorphic rocks. The eastern part is underlain by Paleozoic sedimentary rocks; the western part is underlain by "metamorphosed submarine volcanic rocks and basalts of probable Permo-Triassic age" (Hyndman, 1983). Between about 110 and 70 million years ago (Ma), during the Late Cretaceous, these rocks were intruded by the Atlanta lobe of the granitic Idaho Batholith; these rocks are exposed in much of central Idaho north of the study area and in limited areas of the Owyhee Mountains (Lewis and others, 1987, 2012; Johnson and others, 1988; Jordan, 1994; Beranek and others, 2006). Between about 16.9 and 15.6 Ma, flows of the lower units of the Columbia River Basalt Group were erupted onto these older rocks; these basalts form the acoustic basement beneath the sedimentary and volcanic basin fill of the WSRP (Wood, 2004; Kahle and others, 2011; Barry and others, 2013). Northwest of the WSRP, the north-south trending Weiser embayment formed; this structural basin filled with units of the Columbia River Basalt Group (Fitzgerald, 1982). The basalts in the Weiser embayment are overlain by fluvial sands and lacustrine clays of the Payette Formation, but these sediments thin to the south and are apparently absent south of the Payette River (Feeney and others, 2018; Wood and others, 2018).

Adjacent to the current-day WSRP to the southwest, the north-south trending Oregon-Idaho graben began subsiding about 15.5 Ma and then filled with sediments and interbedded basaltic to rhyolitic flows of the Succor (or Sucker) Creek
Formation (Lawrence, 1988; Cummings and others, 2000; Beranek and others, 2006). Wood and Clemens (2002) noted that the Oregon-Idaho graben and Weiser embayment were formed somewhat contemporaneously and have similar structural patterns.

The WSRP, a "northwest-trending, fault-bounded rift basin," began forming about $11 \mathrm{Ma}$ as the Yellowstone hotspot tracked to the south and east of the basin (Beranek and others, 2006). This faulting was mostly finished by about $9 \mathrm{Ma}$, with total displacement ranging from about 7,200 $\mathrm{ft}$ in the northeast to 9,200 ft in the southwest (Wood and Clemens, 2002). At about the same time (11.7 to $10.6 \mathrm{Ma}$ ), the Jump Creek Rhyolite was erupted from a volcanic center near the current-day Lake Lowell (Ekren and others, 1984; Bonnichsen and others, 2004) (fig. 1). The Jump Creek Rhyolite is chemically different and older than the Idavada Volcanics of Malde and Powers (1962).

Deposition of the Chalk Hills Formation (apparently equivalent to the Poison Creek Formation) started about 10-8 Ma and appears to represent the earliest large lake in the WSRP (Kimmel, 1982; Perkins and others, 1998; Wood and Clemens, 2002; Feeney and others, 2018). The primary lithology is mudstone, but the unit also contains volcanic ash beds and subaqueous basalt flows. About 6-5 Ma, the Chalk Hills Lake disappeared or shrank dramatically, resulting in a depositional hiatus and erosion of the lacustrine sediments: about 1 million years (m.y.) of sedimentary record is missing at the angular unconformity that marks the boundary between the Chalk Hills Formation and the overlying Glenns Ferry Formation (Kimmel, 1979, 1982; Perkins and others, 1998; Wood and Clemens, 2002; Feeney and others, 2018).

The WSRP began filling with water again about $4 \mathrm{Ma}$, creating Lake Idaho and initiating deposition of the Glenns Ferry Formation (Repenning and others, 1995; Wood and Clemens, 2002; Feeney and others, 2018). Although clay and silt were primarily deposited in the deeper parts of the lake, tributary streams deposited sands and gravels as deltas where they entered the lake (Squires and others, 1992; Wood and Clemens, 2002). As the lake neared its highest stand and evaporation caused the lake to become more alkaline, an oolitic shoreline sand was deposited, represented by the Shoofly oolite on the southern margin of the WSRP and the Terteling Springs Formation on the northern margin (Swirydczuk and others, 1979, 1980; Burnham and Wood, 1982; Wood and Clemens, 2002). Wood and Clemens (2002) posited that Lake Idaho rose until it found an outlet in Hells Canyon (downstream from Farewell Bend) on the Snake River (fig. 1) no later than 1.67 Ma. Based on fossil fish assemblages, VanTassell and others (2001) and Smith and others (2000) date the connection of Lake Idaho to the Columbia River drainage between about 3.8 and $2 \mathrm{Ma}$. Other authors using similar evidence have argued that Lake Idaho had another outlet for most of its existence before it connected to the Columbia River system, most likely draining through Oregon or Nevada to California (Wheeler and Cook, 1954; Othberg, 1994; Repenning and others, 1995). 


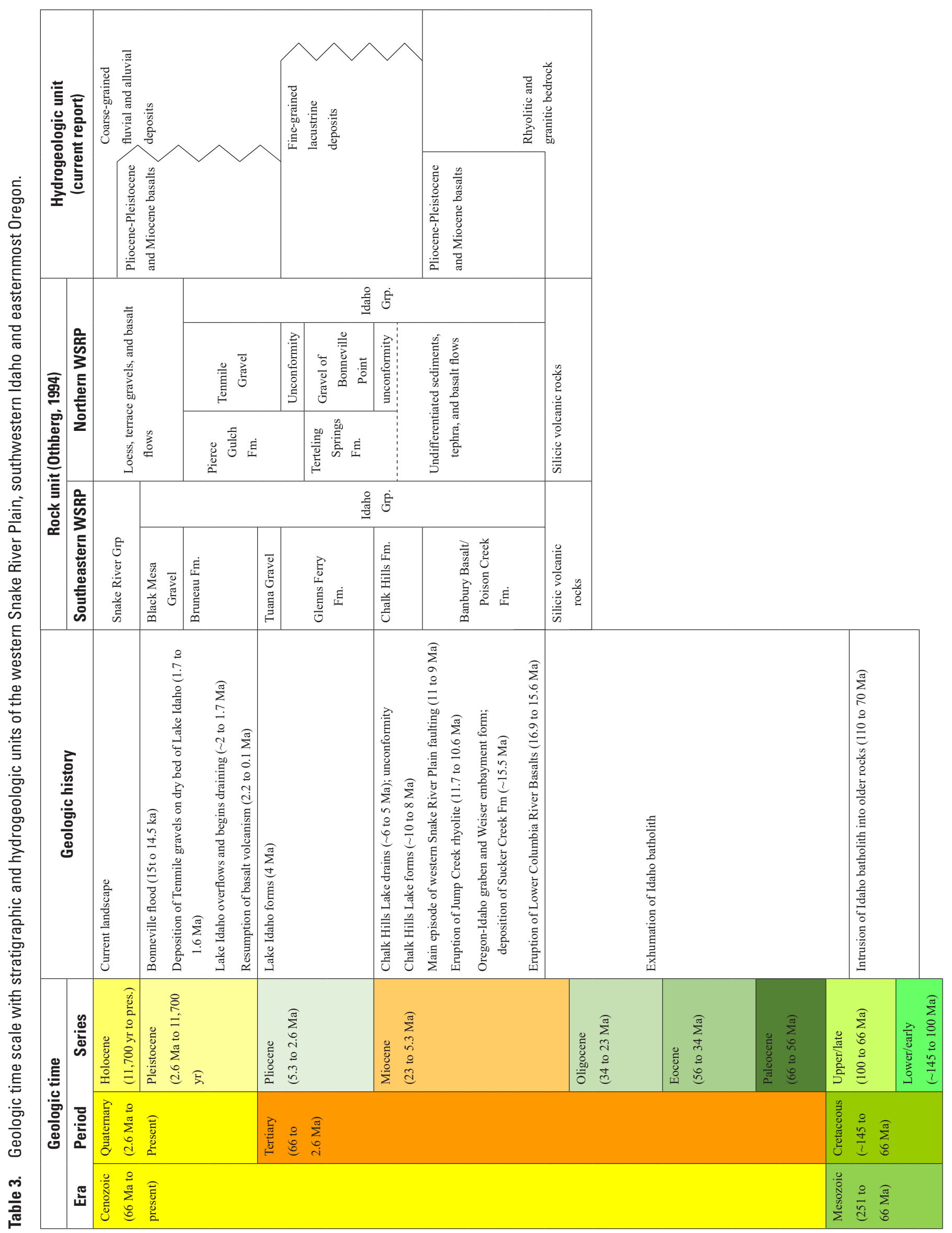


Starting about 2.2 Ma, basalt volcanism resumed in the WSRP and surrounding areas and continued until about 0.1 Ma (Bonnichsen and others, 1997; Wood and Clemens, 2002). Some of these flows were initially erupted into the water of Lake Idaho; as lake levels declined, later deposits were erupted onto the dry lake bed (Godchaux and others, 1992).

After Lake Idaho began flowing through the Hells Canyon outlet, it began downcutting, and lake levels declined (Wood and Clemens, 2002). This caused streams "emptying onto the western plain...to prograde coarse-braided channel gravel deposits across the broad, nearly flat surface of the plain" about 1.7-1.6 Ma (Othberg, 1994). Othberg (1994) named these deposits the Tenmile gravel and indicated that they were the first in a sequence of eight terrace gravels in the Boise Valley deposited during episodic downcutting of the Hells Canyon outlet, possibly in concert with glacial cycles in the Pleistocene. Gilbert and others (1983) recognized six terrace gravels in the Payette River Valley; Feeney and others (2018) simplified this to four.

About 15-14.5 thousand years ago (ka), Lake Bonneville, a large Pleistocene lake in northwestern Utah, reached its maximum height and spilled over into the Snake River drainage. The erosion and failure of the natural dam caused a catastrophic flood that traveled down the Snake River and was temporarily dammed at Hells Canyon. The resultant slack water backed up into the Boise, Payette, and Weiser River valleys and deposited silt and sand to an altitude of about 2,430 ft (O'Connor, 1990; Lewis and others, 2012). Since the Pleistocene, rivers and streams have eroded and partially filled their valleys with unconsolidated sediment in response to tectonic activity and fluctuations in climate.

\section{Hydrogeologic Units}

Hydrogeologic (or hydrostratigraphic) units are "any soil or rock unit or zone which by virtue of its hydraulic properties has a distinct influence on the storage or movement of groundwater" (American Nuclear Society, 1980; Isensee and others, 1989). Because the hydraulic properties of a rock are frequently controlled by its lithology, hydrogeologic units often correspond to lithostratigraphic units. Previous workers have defined hydrogeologic units in the WSRP aquifer system differently. The studies most relevant to the current work are those of Whitehead (1986, 1992), Newton (1991), Squires and others (1992), and Wood (1997b) (table 4). These authors used different approaches to delineate their hydrogeologic units: Whitehead $(1986,1992)$ and Newton (1991) defined rock units based on lithology and age; alternatively, Squires and others (1992), and Wood (1997b) used depositional environments or facies.

Whitehead $(1986,1992)$ described the hydrogeology of both the ESRP and WSRP regional aquifer systems. Although he did not use the term "hydrogeologic unit," he defined and described seven geologic units that form the two aquifer systems, of which five are present in the WSRP. Newton (1991) also did not use the term "hydrogeologic unit" but described the WSRP aquifer system as "composed of three major rock units," essentially consolidating Whitehead's $(1986,1992)$ units as shown in table 4.

Squires and others (1992) were primarily concerned with the portion of the aquifer system used for municipal supply in the Boise area; that is, the uppermost $1,000 \mathrm{ft}$ of sediment. They defined five hydrogeologic units based on depositional facies with differing lithologic and hydrologic properties (table 4). Wood (1997b) used a similar approach for the entire WSRP (table 4). The stratigraphic/lithologic approach of Whitehead $(1986,1992)$ and Newton (1991) emphasizes vertical changes in the hydrogeology, while the facies approach of Squires and others (1992) and Wood (1997b) also accounts for horizontal variability.

The definition of hydrogeologic units in the current report is a combination of the two approaches and is based on lithology: different rock types that represent changes in the depositional environment. This approach is similar to that of Wood (1997b). The four hydrogeologic units discussed here are referred to by their principal lithology. These hydrogeologic units are: coarse-grained fluvial and alluvial deposits, Pliocene-Pleistocene and Miocene basalts, fine-grained lacustrine deposits, and granitic and rhyolitic bedrock (table 4).

As suggested by the geologic history described in the "Geologic Setting" section, in general, the lower aquifer is predominantly composed of fine-grained sediment and the upper portion of the aquifer tends to be composed of coarse-grained sediment. However, as is typical in Cenozoic sedimentary basin-fill deposits, there can be significant variation within a given hydrogeologic unit; additionally, the different hydrogeologic units are both interbedded and interfingered. For these reasons, hydraulic properties can vary significantly over a short horizontal or vertical distance. 
Table 4. Summary of western Snake River Plain hydrogeologic units used by previous authors and the current report.

\begin{tabular}{|c|c|}
\hline \multicolumn{2}{|c|}{ Rock-based units } \\
\hline Whitehead $(1986,1992)$ & Newton (1991) \\
\hline Younger alluvium & Upper unit: Tertiary-Quaternary sedimentary and volcanic rocks \\
\hline Older alluvium & \multirow[t]{2}{*}{ Middle unit: Tertiary-Quaternary sedimentary and volcanic rocks } \\
\hline Older basalt & \\
\hline
\end{tabular}

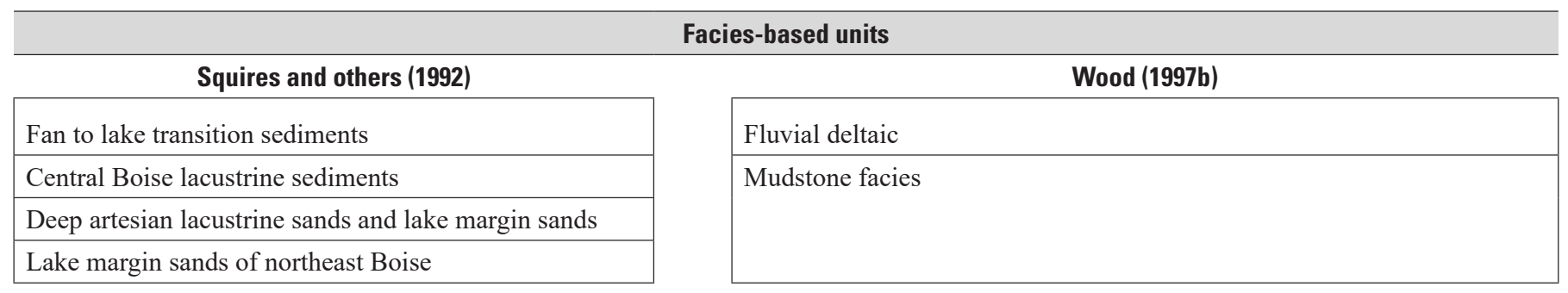

\section{Lithology-based units}

The current report

\begin{tabular}{|l|}
\hline Coarse-grained fluvial and alluvial deposits \\
\hline Pliocene-Pleistocene and Miocene basalts \\
\hline Fine-grained lacustrine deposits \\
\hline Rhyolitic and granitic bedrock \\
\hline
\end{tabular}

\section{Coarse-Grained Fluvial and Alluvial Deposits}

Coarse-grained fluvial and alluvial deposits are the source of water for most wells completed in the WSRP aquifer system. These sediments were deposited in two depositional environments: (1) sediments deposited on the northern and southern margins of the Chalk Hills lake and Lake Idaho in the form of alluvial fans and stream or river deltas, and (2) fluvial deposits deposited on the lacustrine sediments of Lake Idaho after the through-flowing Snake River was established and the lake drained. It is the second-largest hydrogeologic unit by volume in the WSRP aquifer system and is composed mostly of sands and gravels with interspersed finer-grained deposits. Because it is the uppermost hydrogeologic unit in much of the WSRP, many wells are completed in it and the water is used for a wide variety of uses. The coarse-grained fluvial and alluvial deposits are largely equivalent to Wood's (1997b) fluvial-deltaic facies.

\section{Pliocene-Pleistocene and Miocene Basalts}

Pliocene-Pleistocene basalts (and related deposits such as scoria or cinders) form much of the WSRP aquifer system in the southeastern part of the study area. It is the third-largest hydrogeologic unit by volume in the WSRP aquifer system. These basalts were erupted both on land and within Lake Idaho; they interfinger with and are covered by deposits of the two sedimentary hydrogeologic units. Most wells completed in this hydrogeologic unit are used for irrigation or domestic supply.

Miocene basalts of the Columbia River Basalt Group underlie the lacustrine, fluvial, and alluvial sediments and Pliocene-Pleistocene basalts that form the upper parts of the WSRP aquifer system. A structure map of the base of the Pliocene-Pleistocene basalts in the southern portion of the study area shows them separated from the Miocene basalts by several thousand feet (Wood, 1997a). However, in the northern part of the WSRP near Boise (figs. 1, 2, 6), the Pliocene-Pleistocene basalts and Miocene basalts are in direct contact with granitic bedrock. It is therefore difficult to differentiate them from well-driller reports alone. So, although Miocene basalts should be considered part of the basement hydrogeologic unit, they are instead grouped with the younger Pliocene-Pleistocene basalts. 


\section{Fine-Grained Lacustrine Deposits}

Although fine-grained lacustrine deposits are the most extensive hydrogeologic unit in the WSRP aquifer system, it is penetrated by fewer wells because of its generally greater depth. These deposits accumulated in the Chalk Hills lake and Lake Idaho and are primarily composed of clays and silts with some interspersed coarser-grained deposits. Water from wells completed in this hydrogeologic unit is mostly used for municipal, irrigation, industrial, or geothermal supply. The fine-grained lacustrine deposits are largely equivalent to Wood's (1997b) mudstone facies.

\section{Rhyolitic and Granitic Basement}

The coarse-grained fluvial and alluvial deposits, Pliocene-Pleistocene basalts, and fine-grained lacustrine deposits are underlain by bedrock. This bedrock is composed primarily of Miocene rhyolites and other silicic volcanic rocks and Cretaceous granitic rocks of the Idaho batholith. In places sedimentary units are found between different flows of the rhyolite and between the rhyolite and granite. Few wells are completed in this bedrock: in the north-central part of the study area, such wells furnish water for domestic supply and in the northeastern part of the Boise area they provide water for geothermal supply. Petrich and Urban (2004c) described the hydraulic connection between these older units and the overlying sediments and basalts as "limited" based on several lines of evidence.

\section{Hydraulic Properties of Hydrogeologic Units}

It is difficult to estimate the number of single- or multiple-well aquifer tests that exist for the WSRP aquifer system primarily because most are described in unpublished consultants' reports (see section, "Hydrology and Hydrogeology"). Additionally, many of these tests have been interpreted using multiple methods, different well combinations, or reinterpreted in subsequent reports. In some cases, well names and (or) locations are inconsistent or ambiguous adding further uncertainty. It is likely that there are over a thousand different interpretations for specific wells using data from hundreds of aquifer tests conducted in the study area. Additionally, many well-driller reports submitted to the IDWR contain information from short-term single-well tests intended for pump selection. Although methodology exists for the determination of transmissivity from these "pump tests" (Thomasson and others, 1960; Theis and others, 1963), these tests are often of such short duration that such estimates are unreliable.

Hydraulic conductivity describes the ability of a material to transmit water and is a measure of permeability. Vertical hydraulic conductivity in sedimentary aquifers may be one or two orders of magnitude less than that of horizontal hydraulic conductivity; this ratio of vertical to horizontal hydraulic conductivity is referred to as anisotropy. Typical values of horizontal and vertical hydraulic conductivity and anisotropy are shown in table 5 .

Storativity (or storage coefficient) is a measure of the volume of water taken into or released from storage in an aquifer with changes in head. In a confined aquifer it is equal to the specific storage multiplied by aquifer thickness; in an unconfined aquifer it is essentially equal to specific yield. Typical values of specific storage and specific yield are shown in table 5.

Another source of hydraulic properties are calibrated groundwater-flow models. These numbers are typically constrained by typical values found in the literature and (or) from aquifer tests within the model domain. Hydraulic properties from previous groundwater-flow models by Newton (1991), Petrich (2004a), Douglas (2007), and Johnson (2013) are shown in table 5 .

\section{Three-Dimensional Hydrogeologic Framework Model}

As described in the "Methods" section, the 3D HFM was generated with lithologic data from 291 well-driller reports (figs. 5 and 6); the locations of these wells are shown in fig. 4.

A comparison of the 3D HFM with hydrogeologic frameworks developed by previous authors shows broad agreement (figs. 5 and 6). The 3D HFM concurs with the general characterization of the aquifer system as coarser-grained alluvial sediments overlying finer-grained lacustrine sediments with some overlying and interbedded basalts. The 3D HFM and a cross-section by Wood and Clemens (2002, p. 94) show bedrock above $500 \mathrm{ft}$ altitude only in the northeastern part of the model area. The horizontal and vertical distribution of Pliocene-Pleistocene and Miocene basalts in the 3D HFM is in general agreement with previous authors including Whitehead (1992), Othberg and Stanford (1992), and Wood (1997a). 
Table 5. Published ranges for hydraulic conductivity, anisotropy, storativity, specific storage, and specific yield for selected aquifer materials and groundwater-flow models.

[Abbreviations: ft/d, feet per day; ft, foot; do., ditto]

\begin{tabular}{|c|c|c|}
\hline Material & Range of values & Source \\
\hline \multicolumn{3}{|c|}{ Horizontal hydraulic conductivity (ft/d) } \\
\hline Clay & $2.8 \times 10^{-6}-0.13$ & Spitz and Moreno (1996, p. 346) \\
\hline Silty sands, fine sands & $0.028-2.8$ & do. \\
\hline Well-sorted sands, glacial outwash & $2.8-280$ & do. \\
\hline Sand and gravel & $27-650$ & do. \\
\hline Gravel & $130-2.8 \times 10^{5}$ & Spitz and Moreno (1996, p. 347) \\
\hline Basalt & $5.3 \times 10^{-6}-0.13$ & Spitz and Moreno (1996, p. 346) \\
\hline Basalt, permeable & $0.13-1.3 \times 10^{4}$ & do. \\
\hline Basaltic lava and sediments & $510-5.1 \times 10^{4}$ & do. \\
\hline Model layers 1 and 2 & $\approx 0.01-1.0 \times 10^{3}$ & Petrich $(2004$, p. 62$)$ \\
\hline Model layers 3 and 4 & $\approx 0.01-1.0 \times 10^{3}$ & Petrich $(2004$, p. 63$)$ \\
\hline Model 6, layers 1,2 , and 3 & $0.016-50$ & Douglas (2007, appendix D) \\
\hline Model 6, layer 4 & $3.6 \times 10^{-5}-6.0$ & do. \\
\hline Model 6, layer 5 & $0.068-800$ & do. \\
\hline Model 6, layers 6 and 7 & $0.078-1.5 \times 10^{3}$ & do. \\
\hline Model 6, layer 8 & $1.9 \times 10^{-4}-790$ & do. \\
\hline Model layer 1 & $\approx 0-2.0 \times 10^{3}$ & Johnson $(2013$, p. 26) \\
\hline Model layer 2 & $\approx 1.0 \times 10^{-6}-100$ & Petrich (2004, p. 64) \\
\hline Model layers 3 and 4 & $\approx 1.0 \times 10^{-4}-1$ & do. \\
\hline Model layer 1 & $\approx 1.0 \times 10^{-5}-1$ & Johnson (2013, p. 28) \\
\hline Model layer 2 & $\approx 4.1 \times 10^{-5}-1$ & Johnson (2013, p. 29) \\
\hline Model layer 3 & $\approx 3.7 \times 10^{-4}-1$ & do. \\
\hline Model layer 4 & $\approx 3.7 \times 10^{-4}-1$ & Johnson $(2013$, p. 30) \\
\hline \multicolumn{3}{|c|}{ Anisotropy (dimensionless) } \\
\hline Clay & $0.025-1.4$ & Spitz and Moreno (1996, p. 351) \\
\hline Sand, silt, and clay & $<0.1$ & do. \\
\hline Sandstone & $0.5-1$ & do. \\
\hline Shale & $0.1-0.5$ & do. \\
\hline Siltstone-shale & $0.1-0.107$ & do. \\
\hline Silt, organic & $0.6-0.8$ & do. \\
\hline Model 1, layer 5 & 0.1 & Douglas $(2007$, p. 82) \\
\hline
\end{tabular}


Table 5. Published ranges for hydraulic conductivity, anisotropy, storativity, specific storage, and specific yield for selected aquifer materials and groundwater-flow models.-Continued

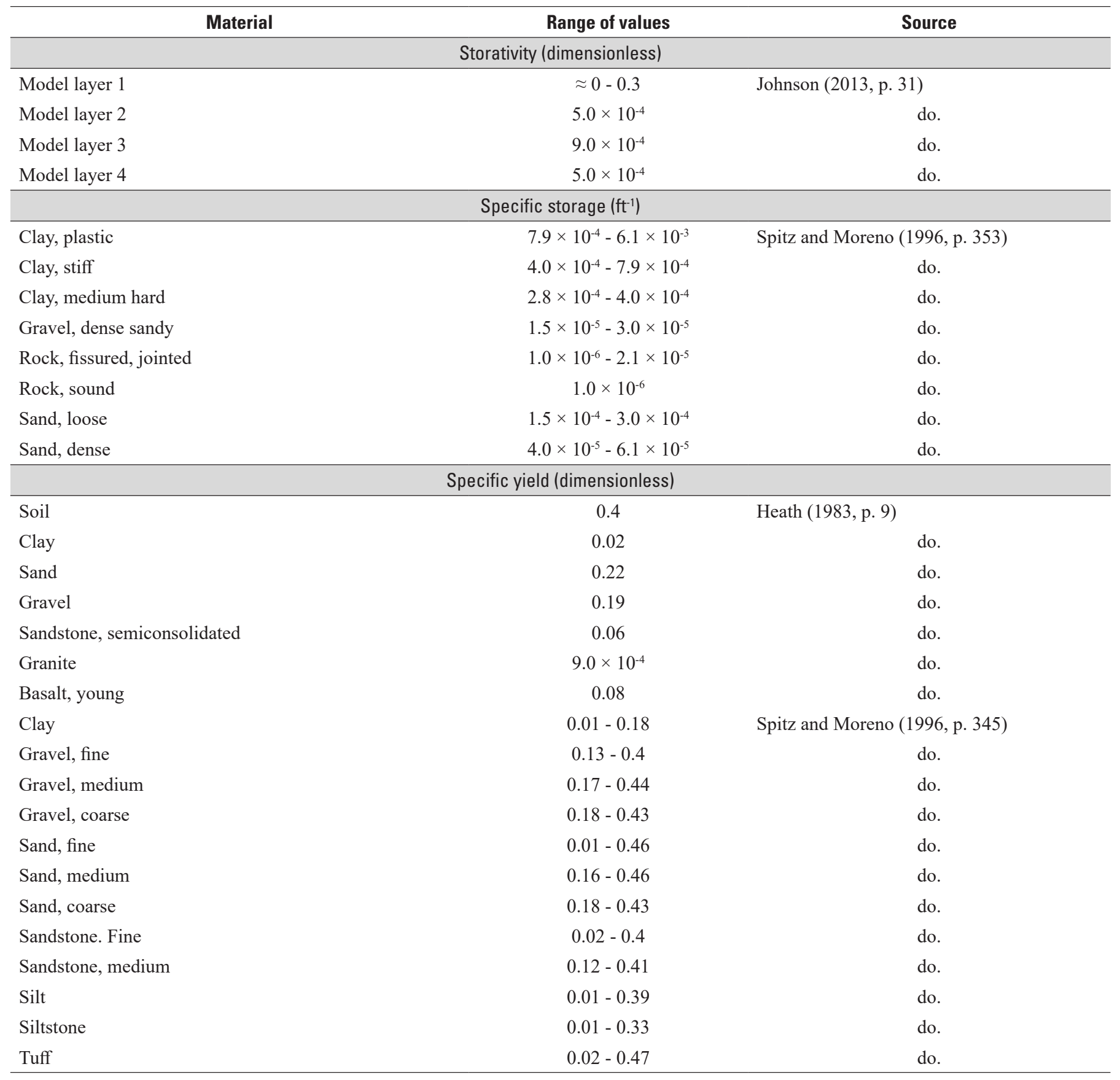




\section{Limitations and Uncertainties}

The Cenozoic history and basin-fill deposits of the WSRP bear similarities to those of other areas such as within the series of basins along the Rio Grande River in New Mexico that are filled with Santa Fe Group deposits. On a generalized regional scale, the initial lower sediments were deposited in a closed basin and tend to be finer-grained; as rivers or streams became through-flowing, mainly coarser sediments were deposited as the upper portion of the basin fill. However, lithology within these sediments is often more variable on a local scale. Lake levels and the size of alluvium carried by streams fluctuated due to tectonism or climate cycles. As a result, streams varied between straight, meandering, and braided patterns and cycled between incision and deposition. The result is that the lithology of basin-fill sediments often exhibits extreme variability over very short horizontal and vertical distances.

Well-driller reports introduce uncertainty in several ways. As explained in the "Well Data" section, although reported well locations on more recent well-driller reports are often established using a GPS, locations on older reports were established with maps and given in the PLSS format. This latter method locates wells to a 10 -acre tract at best; often well locations are reported to the section level (a $1-\mathrm{mi}^{2}$ tract). Because well-surface altitudes in the 3D HFM are adjusted to a grid derived from 30-m DEMs, location errors may cause errors in altitude as well. Another source of uncertainty is that lithologic descriptions of rock and sediment penetrated in a borehole may vary considerably between drillers. Finally, mud- and air-rotary drilling methods tend to cause an underestimation of the amount of fine-grained sediment, especially in saturated sediments.

The grouping of lithologies found in well-driller reports into four hydrogeologic units oversimplifies the subsurface; thus, gradual transitions are lost. Similarly, rare or ambiguous lithologies such as "lignite," "wood," or "volcanics" may be incorrectly assigned to a hydrogeologic unit.

The lack of data in some areas and at lower depths contribute to uncertainty. Some areas within the 3D HFM boundary contain few wells, such as north of Parma or the southeastern part of the model area (fig. 4). Similarly, because most wells are drilled to the minimum possible depth with sufficient water, the number of well completions decline with depth. Thus, the 3D HFM contains more uncertainty with increasing depth. In these areas that lack data, the interpolation algorithm used in Rockworks $17^{\mathrm{TM}}$ may not calculate lithologies correctly.

Where faults cause juxtaposition of sedimentary hydrogeologic units with bedrock or basalts, such as the east Boise fault of Squires and others (1992), the fault is implicitly represented in the 3D HFM. Otherwise, faults were not included in the current model for several reasons. Most mapped faults occur in older bedrock either bounding or underlying the WSRP aquifer system. The faults that do occur within the coarse- and fine-grained WSRP hydrogeologic units tend to be covered by younger sediment and thus have uncertain locations. Additionally, the dip and extent of these faults in the subsurface is usually uncertain.

\section{Application to a Groundwater-Flow Model}

The 3D HFM can be used to delineate layers for a groundwater-flow model, although vertical heterogeneity would probably yield only two to three layers that would likely be unrepresentative of head conditions within the aquifer system. A more representative approach would be to define groundwater-flow model layers on the basis of head conditions and then delineate hydraulic-property zonation within a given layer with the 3D HFM. Several methods are available in Rockworks $17^{\mathrm{TM}}$ to accomplish such zonation. The first approach extracts a planar or irregular surface from within the 3D HFM that shows hydrogeologic units on this surface. Rockworks $17^{\mathrm{TM}}$ contains export tools to create zone files directly for MODFLOW or Groundwater Vistas ${ }^{\mathrm{TM}}$ in the same manner. The second approach extracts a three-dimensional horizontal planar body of designated thickness from the 3D HFM and converts it to a two-dimensional grid. The planar body may be more than one voxel thick, if so, the hydrogeologic unit assigned to the grid value may be determined several ways, including the value at a specific plane with the body or the arithmetic or geometric means of the vertical voxel values. Depending on how groundwater-flow model layers are defined, it is possible that both approaches could be used to create hydrogeologic-unit zonation within the model layer. The cell size of a groundwater-flow model may require further simplification of the hydrogeologic-unit zonation to eliminate small inliers or irregular shapes.

\section{Conceptual Groundwater Budget}

A water budget is an accounting of water and its movement in a hydrologic system for a specified time period; it may include groundwater, surface water, or both. Water budgets allow water-resource scientists and managers to understand how the hydrologic system functions, and they are necessary for the construction of groundwater-flow models. Some inflows and outflows of a system cannot be measured directly (such as subsurface flow into or out of an aquifer) and must be estimated. The result is uncertainty about individual components as well as total inflow and outflow volumes. 


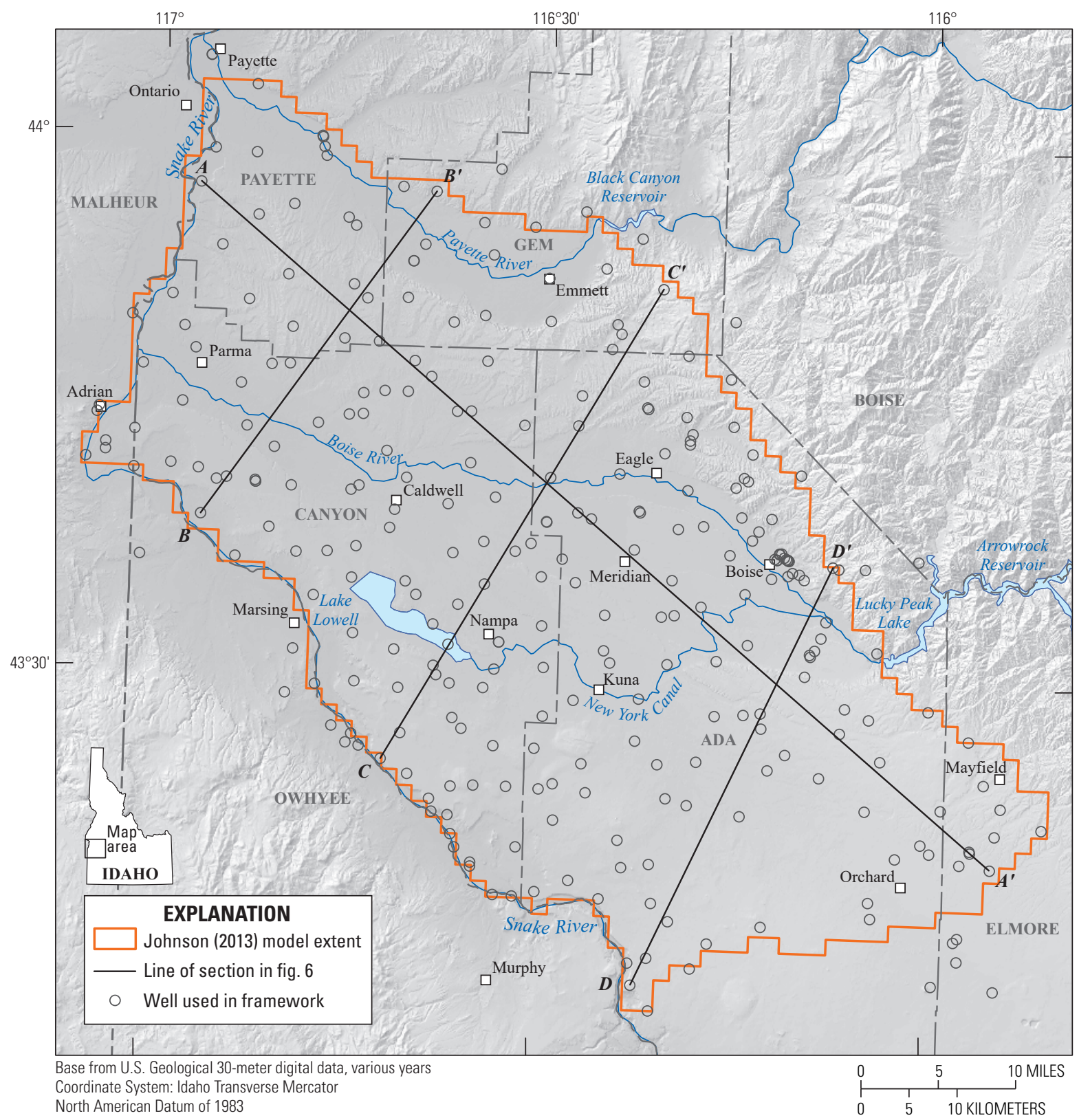

Figure 4. Wells used to generate the three-dimensional hydrogeologic framework and lines of section, western Snake River Plain, southwestern Idaho and easternmost Oregon. 


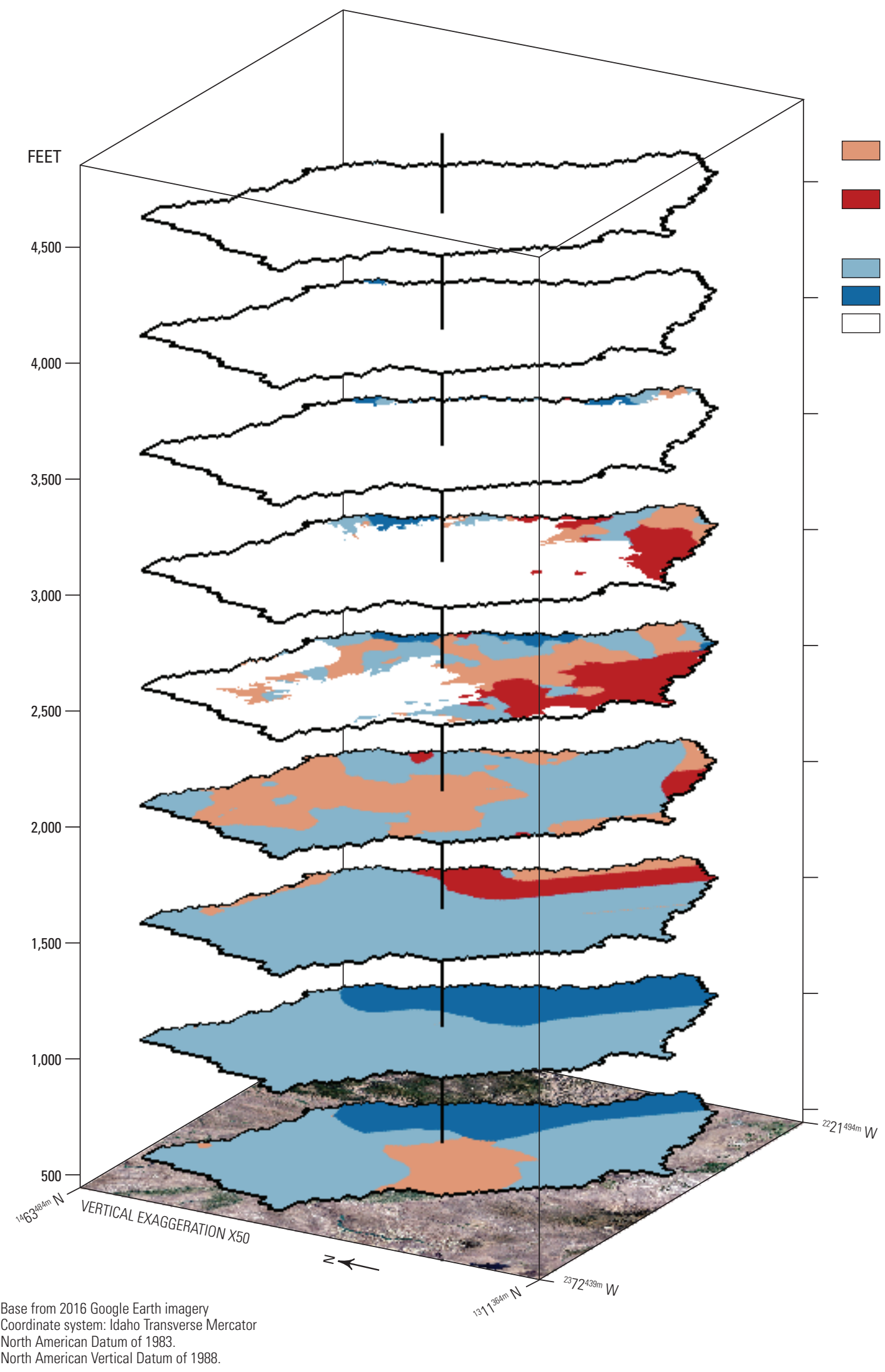

\section{EXPLANATION}

Hydrogeologic unit

Coarse-grained fluvial and alluvial deposits

Basalt, undifferentiated (include Pliocene-Pleistocene and Miocene basalts)

Fine-grained lacustrine deposits Granitic and rhyolitic bedrock No data, above land surface

Figure 5. Perspective view of horizontal slices at 500-ft intervals through the three-dimensional hydrogeologic framework model. View is from the southwest looking to the northeast from an elevation of 20 degrees above the horizon. Vertical exaggeration is 50 times. Horizontal and vertical scale is variable owing to the effects of perspective view. Colors may appear variable owing to the effects of illumination from above and southeast. 


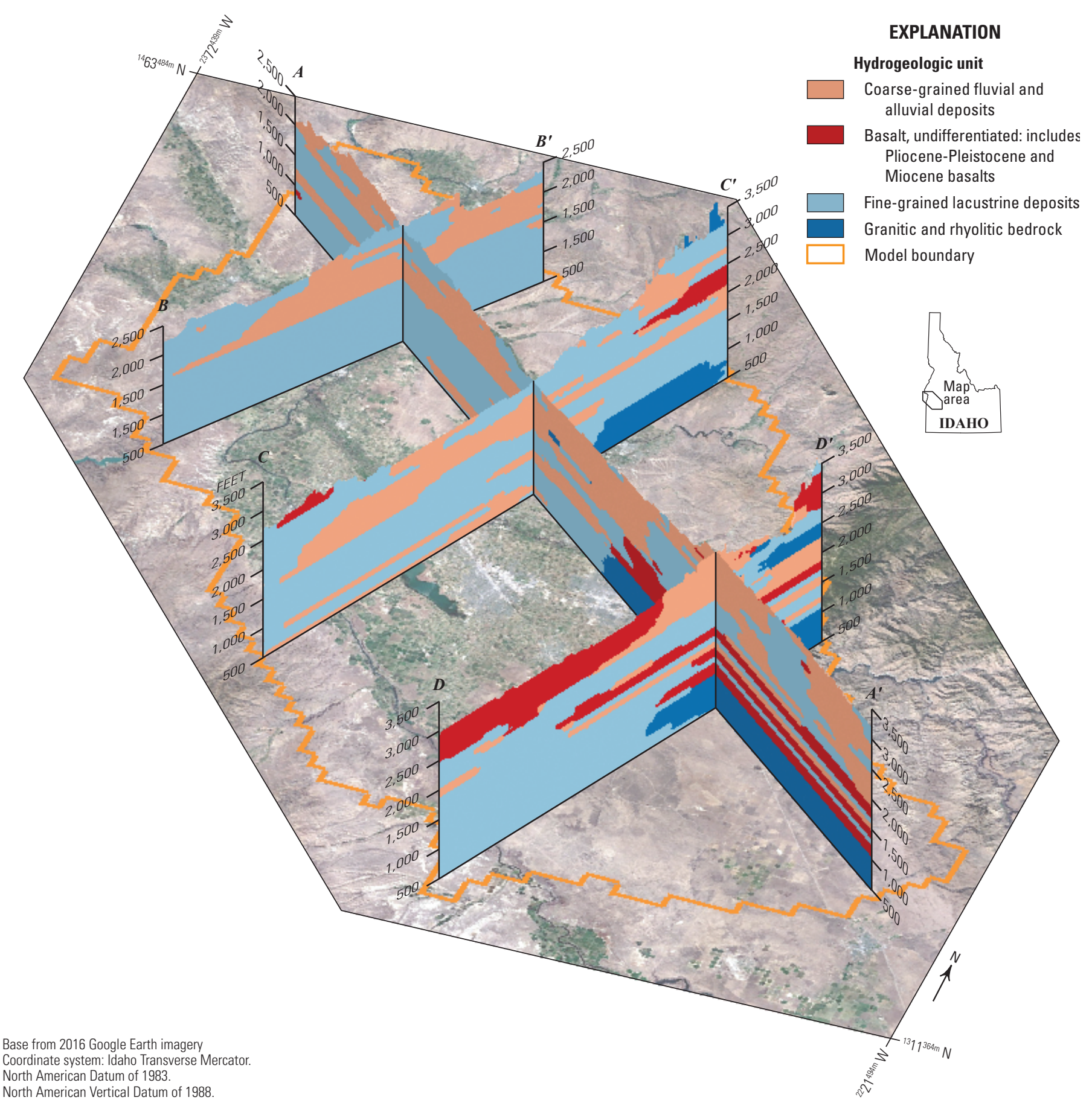

Figure 6. Perspective view of vertical cross sections of the three-dimensional hydrogeologic framework model. View is from the southeast looking to the northwest from an elevation of 40 degrees above the horizon. Vertical exaggeration is 5 times. Horizontal and vertical scale is variable owing to the effects of perspective view. Colors appear variable owing to the effects of illumination from above and southeast. Lines of section are shown on figure 4. 
As described in the "Previous Work" section, a number of groundwater budgets have been developed for substantial portions of the WSRP; the most useful for the current report are those of Newton (1991), Urban (2004), Schmidt and others (2008), and Sukow (2012). The Newton (1991) groundwater budget shown in table 6 is for 1980 and covers the entire WSRP (fig. 3). Urban (2004) constructed 1996 and 2000 groundwater budgets for the area of Petrich's (2004a) groundwater-flow model of the Treasure Valley; table 6 shows the means of the two (fig. 3). Schmidt and others (2008) constructed a combined groundwater/surface-water budget for the Treasure Valley to which Sukow (2012) added data for the Payette River valley for use in Johnson's (2013) groundwater-flow model (table 6; fig. 3). Table 6 shows all of the components of the Newton (1991) and Urban (2004) budgets. In table 6, the Schmidt and others (2008) and Sukow (2012) budgets are combined and only groundwater budget components are shown. Caution is warranted in comparing the budgets because of differing areas, time periods, and the manner in which individual budget components are combined. Particularly, the Newton (1991) model domain contains over twice the land area of the other budgets, including large areas of uncultivated desert and a large number of constant flux boundary cells representing underflow. The reader is referred to the original publications for details.

\section{Inflows}

Inflow to the aquifer (or recharge) occurs from several main sources: seepage from irrigation canals, direct infiltration from precipitation and excess irrigation water, seepage from the Boise and Payette Rivers and Lake Lowell, and subsurface inflow from adjoining uplands.

Newton (1991) estimated that 80 percent of total recharge to the WSRP aquifer system was from infiltration of surface-water irrigation (including canal seepage), with an additional 2.3 percent from infiltration of precipitation. The largest component of Urban's (2004) groundwater recharge was canal seepage ( 54 percent), followed by flood irrigation and precipitation (33 percent) and recharge from precipitation by other land uses (5.4 percent), for a total of 92 percent. The combined Schmidt and others (2008) and Sukow (2012) budgets estimate that of the total groundwater recharge, 48 percent is canal seepage, 46 percent is total on-farm infiltration, 1.6 percent is infiltration of precipitation on non-irrigated lands, and less than 1 percent is infiltration of precipitation on domestic, commercial, municipal, and industrial lands.

Underflow into the WSRP aquifer system was estimated as 18 percent of the total groundwater recharge by Newton (1991), less than 1 percent by Urban (2004), and 4.1 percent by Sukow (2012).

Urban (2004) estimated that seepage from Lake Lowell was 20,100 acre-ft or about 2 percent of the total inflow to the aquifer. Schmidt and others (2008) estimated that 3,752 acre-ft seeped into Lake Lowell representing less than 1 percent of the total outflow from the aquifer.

Urban (2004) identified percolation from rural domestic septic systems as an additional component of less than 1 percent of the total groundwater recharge.

\section{Outflows}

The three main components of outflow (or discharge) from the aquifer system are: discharge to surface water (rivers, agricultural drains, streams, and Lake Lowell), groundwater pumping, and to a much lesser degree, direct evapotranspiration from groundwater.

Newton (1991) and Urban (2004) estimated that of total groundwater discharge, 83 and 82 percent, respectively, was to rivers and drains. The combined Schmidt and others (2008) and Sukow (2012) budgets show that 51 percent of total groundwater discharge is to agricultural drains and 33 percent to rivers.

Pumpage from wells is considered the second-largest source of groundwater discharge in all four water budgets. Newton (1991) estimated 17 percent and Urban (2004) 18 percent. The combined Schmidt and others (2008) and Sukow (2012) budgets divided pumpage into irrigation ( 8.9 percent) and domestic, commercial, municipal, and industrial (5.6 percent).

The combined Schmidt and others (2008) and Sukow (2012) budgets estimated aquifer discharge to wetlands and Lake Lowell as 1.4 and less than 1 percent of the total discharge, respectively. None of the water budgets included direct evapotranspiration from groundwater (by riparian vegetation) as a separate component; however, Newton (1991) stated that, "Although [evapotranspiration] from shallow ground water may be significant in local areas, [it] is negligible relative to the total ground-water budget." 
Table 6. Summary of selected western Snake River Plain groundwater budgets by previous authors.

[Component names and significant figures are as shown in the originals. Abbreviations: acre-ft/yr, acre-feet per year; -, not applicable]

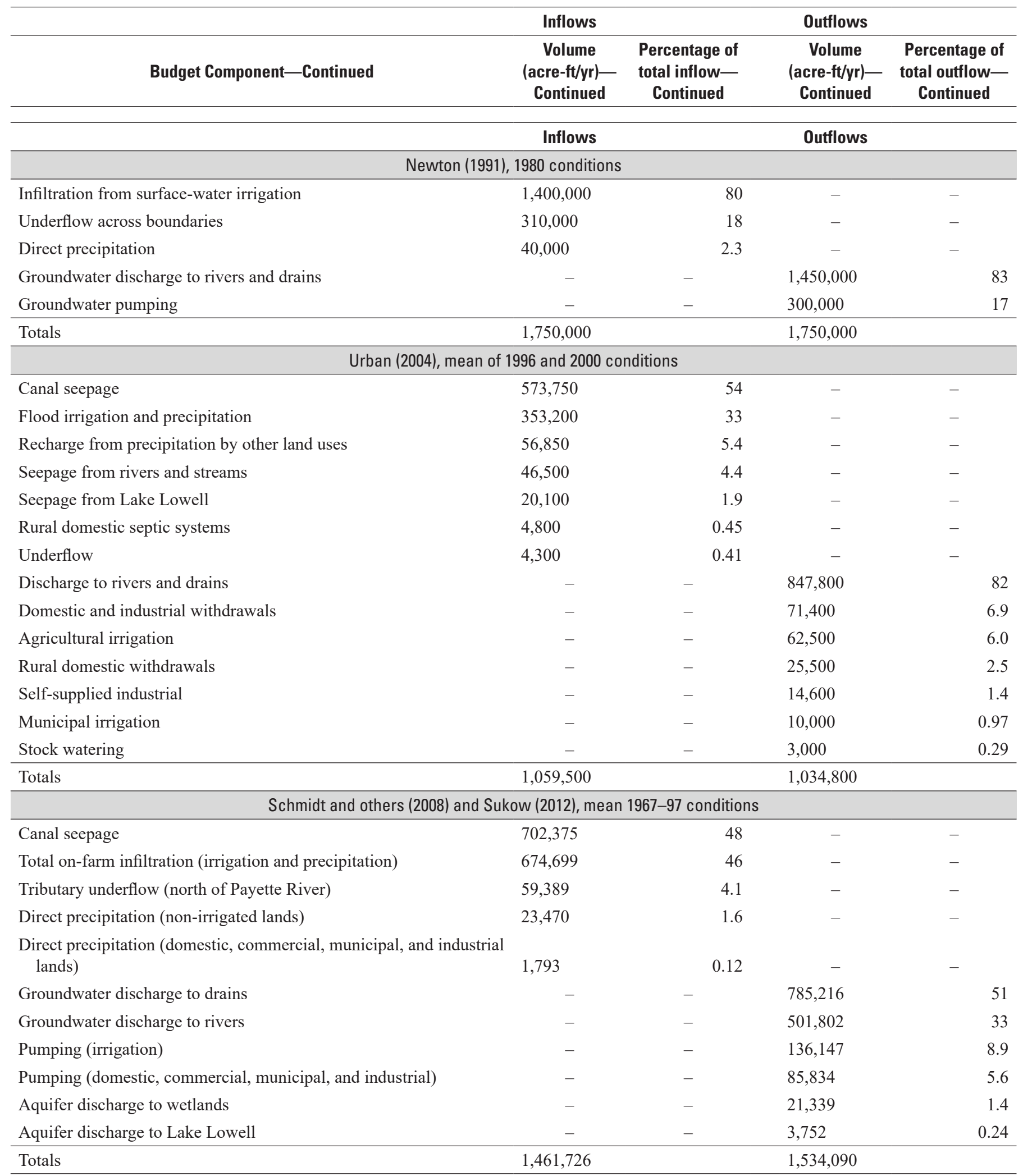




\section{Summary}

The population of the Treasure Valley and surrounding area of southwestern Idaho and easternmost Oregon more than doubled between 1990 and 2017; in 2017 it contained about 41 percent of the population of Idaho (U.S. Census Bureau, 2019). Because most of the population of the area depends on groundwater for domestic supply, either from domestic or municipal-supply wells, current and projected rapid population growth in this area has caused concern about the long-term sustainability of the groundwater resource. The U.S. Geological Survey, in cooperation with the Idaho Water Resource Board and the Idaho Department of Water Resources, began a project in 2016 to construct a numerical groundwater-flow model of the westernmost western Snake River Plain (WSRP) aquifer system in the area. As part of this project a three-dimensional hydrogeologic framework model (3D HFM) of the aquifer system was generated using Rockware Rockworks17 TM three-dimensional modeling software with lithologic data from 291 well-driller reports as the primary data source.

The areal extent of the 3D HFM corresponds to the model domain of a groundwater-flow model by Johnson (2013). The voxel size of the 3D HFM was 400-m by $400-\mathrm{m}$ in the horizontal dimension and $50 \mathrm{ft}$ in the vertical dimension (1,312-ft by $50-\mathrm{ft}$ or $400-\mathrm{m}$ by $15-\mathrm{m})$, which is sufficient for the construction of a regional groundwater-flow model. A total of 28 lithology types were defined in Rockworks 17 ${ }^{\text {TM }}$ based upon well-driller report descriptions and then assigned to one of four major hydrogeologic units: coarse-grained fluvial and alluvial deposits, Pliocene-Pleistocene and Miocene basalts, fine-grained lacustrine deposits, and granitic and rhyolitic bedrock. Generally, the 3D HFM is in agreement with the geologic history of the WSRP and hydrogeologic frameworks developed by previous authors.

The major components of inflow (or recharge) to the WSRP aquifer system are seepage from irrigation canals, direct infiltration from precipitation and excess irrigation water, seepage from the Boise and Payette Rivers and Lake Lowell, and subsurface inflow from adjoining uplands. The major components of outflow (or discharge) from the aquifer system are discharge to surface water (rivers, agricultural drains, streams, and Lake Lowell), groundwater pumping, and to a much lesser degree, direct evapotranspiration from groundwater.

\section{References Cited}

Adkins, C.B., and Bartolino, J.R., 2010, Distribution of isotopic and environmental tracers in groundwater, Northern Ada County, Southwestern Idaho: U.S. Geological Survey Scientific Investigations Report 2010-5144, 30 p. [Also available at https://doi.org/10.3133/sir20105144.].
American Nuclear Society, 1980, American national standard for evaluation of radionuclide transport in groundwater for nuclear power sites: La Grange Park, Illinois, ANSI/ ANS-2.17-1980, American Nuclear Society. [Also available at https://www.nrc.gov/docs/ML0610/ML061000654.pdf.]

Baker, S.J., 1991, Ground-water conditions in the Dry Creek area, Eagle, Idaho: Boise, Idaho Department of Water Resources Open-File Report, 27 p., accessed July 23, 2018, at http://www.idwr.idaho.gov/files/publications/199106OFR-gw-conditions-drycr-eagle-id.pdf

Baldwin, J.A., and Wicherski, Bruce, 1994, Ground water and soils reconnaissance of the lower Payette area, Payette County, Idaho: Boise, Idaho Department of Environmental Quality Ground Water Technical Report 5, 54 p., 1 appendix. [Also available at http://www.deq.idaho.gov/ media/470592-_water_data_reports_ground_water_payette_ county_soils_recon.pdf].

Bartolino, J.R., and Cole, J.C., 2002, Ground-water resources of the Middle Rio Grande Basin, New Mexico: U.S. Geological Survey Circular 1222, 132 p. [Also available at https://doi.org/10.3133/cir1222.].

Bartolino, J.R., and Hopkins, C.B., 2016, Ambient water quality in aquifers used for drinking-water supplies, Gem County, Idaho, 2015: U.S. Geological Survey Scientific Investigations Report 2016-5170, 33 p., 1 appendix. [Also available at https://doi.org/10.3133/ sir20165170https://doi.org/10.3133/sir20165170.]

Barry, T.L., Kelley, S.P., Reidel, S.P., Camp, V.E., Self, S., Jarboe, N.A., Duncan, R.A., and Renne, P.R., 2013, Eruption chronology of the Columbia River Basalt Group, in Reidel, S.P., Camp, V.E., Ross, M.E., Wolff, J.A., Martin, B.S., Tolan, T.L., and Wells, R.E., eds., The Columbia River Flood Basalt Province: Geological Society of America Special Paper 497, p. 45-66. [Also available at https://doi.org/10.1130/2013.2497(02).].

Bartolino, J.R., and Hopkins, C.B., 2016, Ambient water quality in aquifers used for drinking-water supplies, Gem County, Idaho, 2015: U.S. Geological Survey Scientific Investigations Report 2016-5170, 33 p., 1 appendix. [Also available at https://doi.org/10.3133/ sir20165170https://doi.org/10.3133/sir20165170.]

Beranek, L.P., Link, P.K., and Fanning, C.M., 2006, Miocene to Holocene landscape evolution of the western Snake River Plain region, Idaho-Using the SHRIMP detrital zircon provenance record to track eastward migration of the Yellowstone hotspot: Geological Society of America Bulletin, v. 118, no. 9-10, p. 1027-1050. [Also available at https://doi.org/10.1130/B25896.1.]. 
Berenbrock, C., 1999, Streamflow gains and losses in the lower Boise River Basin, Idaho, 1996-97: U.S. Geological Survey Water-Resources Investigations Report 99-4105, 25 p. [Also available at https://doi.org/10.3133/wri994105.].

Bonnichsen, B., and Godchaux, M.M., 2006a, Geologic map of the Melba quadrangle, Ada and Canyon Counties, Idaho: Moscow, Idaho Geological Survey Digital Web map DWM-79, scale 1:24000, 1 sheet. [Also available at https://www.idahogeology.org/product/dwm-79.]

Bonnichsen, B., and Godchaux, M.M., 2006b, Geologic map of the Murphy 30 X 60-minute quadrangle, Ada, Canyon, Elmore, and Owyhee Counties: Moscow, Idaho Geological Survey Digital Web map 80, scale 1:100,000, 1 sheet. [Also available at https://www.idahogeology.org/ product/DWM-80.]

Bonnichsen, B., McCurry, M., and Godchaux, M.M., 2004, Miocene Snake River Plain rhyolites of the Owyhee Front, Owyhee County, Idaho - Owyhee Mountains to the Boise Foothills, in Haller, K.M., and Wood, S.H., eds., Geological field trips in southern Idaho, eastern Oregon, and northern Nevada: U.S. Geological Survey Open-File Report 2004-1222, p. 156-175. [Also available at https://doi.org/ 10.3133/ofr20041222.].

Bonnichsen, B., White, C., and Godchaux, M.M., 1997, Basaltic volcanism, western Snake River Plain, section in McCurry, M., Bonnichsen, B., White, C., Godchaux, M.M., and Hughes, S.S., 1997, Bimodal basalt-rhyolite magmatism in the central and western Snake River Plain, Idaho and Oregon, in Link, P.K., and Kowallis, B.J., Proterozoic to Recent Stratigraphy, Tectonics, and Volcanology, Utah, Nevada, Southern Idaho and Central Mexico: Brigham Young University Geology Studies, v. 42, pt. 1, p. 381-422]., p. 399-422. [Also available at http://geology.byu.edu/Home/sites/default/files/volume-42part-1-mccurry-bonnichsen-white-godchaux-hughes3.pdf.]

Burnham, W.L., and Wood, S.H., 1992, Geologic map of the Boise South quadrangle, Ada County, Idaho (preprint): Preprint, in review Idaho Geological Survey technical report series, April 22, 1992, 28 p.

Busbee, M.W., Kocar, B.D., and Benner, S.G., 2009, Irrigation produces elevated arsenic in the underlying groundwater of a semi-arid basin in Southwestern Idaho: Applied Geochemistry, v. 24, no. 5, p. 843-859. [Also available at https://doi.org/10.1016/j.apgeochem.2009.01.011.].

Castelin, P.M., and Winner, J.E., 1975, Effects of urbanization on the water resources of the Sun Valley-Ketchum area, Blaine County, Idaho: Boise, Idaho Department of Water Resources, Water Information Bulletin 40, 86 p., accessed October 31, 2018, at http://www.idwr.idaho.gov/files/ publications/wib40-sun-valley-ketchum-area.pdf]
City of Boise, 2019, Geothermal heating: City of Boise website, accessed May 20, 2019, at https://publicworks.cityofboise.org/services/geothermal/]

Cope, E.D., 1883, On the fishes of the Recent and Pilocene lakes of the western part of the Great basin, and of the Idaho Pliocene lake: Proceedings of the Academy of Natural Science, v. 35, p. 134-167. [Also available at https://www.jstor.org/stable/pdf/4060876.pdf.].

Cosgrove, D.M., 2010, Evaluation of ground water models in the Treasure Valley, Idaho Area: Idaho Falls, Western Water Consulting, Inc., 134 p. [Also available at http://www.idwr.idaho.gov/Browse/WaterInfo/EADA/ contractorfindings/.].

Cummings, M.L., Evans, J.G., Ferns, M.L., and Lees, K.R., 2000, Stratigraphic and structural evolution of the middle Miocene synvolcanic Oregon-Idaho graben: Geological Society of America Bulletin, v. 112, p. 668- 682, doi: 0/0016-7606(2000)11210.1130/0016-7606(2000)112<0668: SASEOT>2.3.CO;2. [Also available at https://doi.org/ 10.1130/0016-7606(2000)112.]

Deick, J.F., and Ralston, D.R., 1986, Ground water resources in a portion of Payette County, Idaho: Moscow, Idaho Water Resources Institute, University of Idaho, 96 p. [Also available at http://contentdm.lib.uidaho.edu/u?/idahowater,397.].

Douglas, S.L., 2007, Development of a numerical ground water flow model for the M3 Eagle development area near Eagle, Idaho: Boise, Idaho, Boise State University, Master's thesis, $345 \mathrm{p}$. [Also available at http://www.idwr.idaho.gov/ waterinformation/projects/nac/Publications/PDFs/ SDouglas\%20Thesis\%20Dec\%202007.pdf.]

Ekren, E.B., McIntyre, D.H., and Bennett, E.H., 1984, High-temperature, large-volume, lavalike ash-flow tuffs without calderas in southwestern Idaho: U.S. Geological Survey Professional Paper 1272, 76 p., 2 plates in pocket. [Also available at https://doi.org/10.3133/ pp1272https://doi.org/10.3133/pp1272.]

Etheridge, A.B., 2013, Evaluation of total phosphorus mass balance in the lower Boise River and selected tributaries, southwestern Idaho: U.S. Geological Survey Scientific Investigations Report 2013-5220, 70 p. [Also available at https://doi.org/10.3133/sir20135220.].

Feeney, D.M., Wood, S.H., Lewis, R.S., Phillips, W.M., Cooley, S.W., and Garwood, D.L., 2018, Geologic map of the northeast Emmett quadrangle, Gem County, Idaho: Moscow, Idaho Geological Survey Digital Geologic Map 185, scale 1:24,000, 1 sheet. [Also available at https://www.idahogeology.org/product/dwm-185.] 
Ferns, M.L., Brooks, H.C., Evans, J.G., and Cummings, M.L., 1993, Geologic map of the Vale 30 x 60-minute quadrangle, Malheur County, Oregon, and Owyhee County, Idaho: Oregon Department of Geology and Mineral Industries Geological Map Series GMS-77, scale 1:100,000. [Also available at https://www.oregongeology.org/pubs/gms/ GMS-077.pdf.]

Fetter, C.W., 2001, Applied hydrogeology 4th ed.: Upper Saddle River, New Jersey, Prentice Hall, 598 p.

Fitzgerald, J.F., 1982, Geology and basalt stratigraphy of the Weiser embayment, west-central Idaho, in Bonnichsen, Bill, and Breckenridge, R.M., eds., Cenozoic geology of Idaho: Moscow, Idaho Bureau of Mines and Geology Bulletin 26, p. 101-128. [Also available at https://www.idahogeology.org/Products/reverselook.asp? switch=title\&value=Cenozoic_Geology_of_Idaho.]

Gilbert, J.D., Piety, L., and LaForge, R., 1983, Seismotectonic study, Black Canyon Diversion Dam and Reservoir, Boise Project, Idaho: U.S Bureau of Reclamation Pacific Northwest Regional Office, Geology Branch, 137 p., 8 sheets.

Godchaux, M.M., Bonnichsen, B., and Jenks, M.D., 1992, Types of phreatomagmatic volcanoes in the western Snake River Plain, Idaho, USA: Journal of Volcanology and Geothermal Research, v. 52, no. 1-3, p. 1-25. [Also available at https://doi.org/10.1016/03770273(92)90130-6.].

Heath, R.C., 1983, Basic ground-water hydrology: U.S. Geological Survey Water Supply Paper 2220, 86 p. [Also available at https://doi.org/10.3133/wsp2220.].

Hopkins, C.B., 2013, Recharge sources and residence times of groundwater as determined by geochemical tracers in the Mayfield Area, southwestern Idaho, 2011-12: U.S. Geological Survey Scientific Investigations Report 2013-5115, 38 p. [Also available at https://doi.org/10.3133/ $\operatorname{sir} 20135115$.$] .$

Hutchings, J., and Petrich, C.R., 2002a, Ground water recharge and flow in the regional Treasure Valley aquifer system geochemistry and isotope study: Idaho Water Resources Research Institute, Research Report IWRRI-2002-08, 80 p. [Also available at http://www.idwr.idaho.gov/files/projects/ treasure-valley/TVHP-Geochemistry.pdf.]

Hutchings, J., and Petrich, C.R., 2002b, Influence of canal seepage on aquifer recharge near the New York Canal, Idaho Water Resources Research Institute, Research Report IWRRI-2002-09, 31 p. [Also available at http://www.idwr.idaho.gov/files/projects/treasure-valley/ NYC-2002.pdf.]
Hydro Logic Inc, 2008, Reanalysis of 16 aquifer tests in the greater Eagle-Star area of north Ada County, Idaho: Boise, Hydro Logic Inc., July 4, 2008, 256 p., 4 app. [Also available at https://idwr.idaho.gov/water-data/projects/ north-ada-county/references.html.]

Hyndman, D.W., 1983, The Idaho batholith and associated plutons: Idaho and Western Montana: Memoir of the Geological Society of America, v. 159, p. 213-240. [Also available at https://doi.org/10.1130/MEM159p213https://doi.org/10.1130/MEM159-p213.]

Idaho Department of Labor, 2018, 2017 Idaho labor market and economic report: Idaho Department of Labor, 40 p., May 20, 2019, at https://www.labor.idaho.gov/dnn/Portals/ 0/Publications/Labor\%20Market\%20Report\%202017\%20$\% 20 F I N A L . p d f]$

Idaho Department of Water Resources, 2017, Wells: Idaho Department of Water Resources dataset accessed May 9, 2017, at https://data-idwr.opendata.arcgis.com/ datasets/wells

Idaho Department of Water Resources, 2019a, geothermal resource wells: Idaho Department of Water Resources website, accessed May 20, 2019, at https://idwr.idaho.gov/ wells/geothermal-wells.html

Idaho Department of Water Resources, 2019b, Well driller reports (logs): Idaho Department of Water Resources database, accessed May 20, 2019, at http://www.idwr.idaho.gov/Apps/appsWell/ WCInfoSearchExternal/]

Idaho Geological Survey, 2019, Interactive map, oil and gas and geothermal wells: Idaho Geological Survey GIS dataset, accessed January 18, 2019, at https://www.idahogeology.org/webmap

Idaho Senate Resources and Environment Committee, 2016, Senate Concurrent Resolution 137: Legislature of the State of Idaho, 63rd, 2nd session, 2 p. [Also available at https://legislature.idaho.gov/legislation/2016/ SCR137Bookmark.htm.]

Idaho State Climate Services, 2011, Koppen climate classification for the conterminous United States: GIS dataset, accessed July 18, 2019, at https://catalog.data.gov/ dataset/koppen-climate-classification-for-the-conterminousunited-states63aa7

Isensee, A.R., Johnson, L., Thornhill, J., Nicholson, T.J., Meyer, G., Vecchioli, J., and Laney, R., 1989, Subsurface-water flow and solute transport: federal glossary of selected terms: U.S. Geological Survey unnumbered series, DOI 10.3133/7010027610.3133/70 100276, 38 p. [Also available at https://doi.org/10.3133/ 7010027610.3133/70100276.] 
James, M., Montgomery Consulting Engineers, 1992, City of Boise and Boise Warm Springs Water District, Boise geothermal aquifer study: Boise, James M. Montgomery, Consulting Engineers, Inc., May 1992, 19 p. [Also available at http:/geology.isu.edu/Geothermal/References/ Consultants/Montgomery_1992.pdf.]

Johnson, J., 2013, Development of a transient groundwater model of the Treasure Valley aquifer, Idaho: Boise, Bureau of Reclamation, July 2013, 43 p.

Johnson, K.M., Lewis, R.S., Bennett, E.H., and Kiilsgaard, T.H., 1988, Cretaceous and Tertiary intrusive rocks of south-central Idaho, in, Link, P.K., and Hackett, W.R., Guidebook to the geology of central and southern Idaho: Moscow, Idaho Geological Survey Bulletin 27, p. 55-86. [Also available at https:/www.idahogeology.org/ product/b-27.]

Jordan, B.T., 1994, Emplacement and exhumation of the southeastern Atlantic Lobe of the Idaho Batholith and outlying stocks, south-central Idaho [M.S. Thesis]: Pocatello, Idaho State University, 110 p., 1 plate. [Also available at https://isu.app.box.com/v/Jordan-1994.]

Kahle, S.C., Morgan, D.S., Welch, W.B., Ely, D.M., Hinkle, S.R., Vaccaro, J.J., and Orzol, L.L., 2011, Hydrogeologic framework and hydrologic budget components of the Columbia Plateau Regional Aquifer System, Washington, Oregon, and Idaho: U.S. Geological Survey Scientific Investigations Report 2011-5124, 66 p. [Also available at https://doi.org/10.3133/sir20115124.].

Kimmel, P.G., 1979, Stratigraphy and paleoenvironments of the Miocene Chalk Hills Formation and Pliocene Glenns Ferry Formation in the western Snake River Plain, Idaho: Ph.D. Thesis, Univ. of Michigan, 331 p.

Kimmel, P.G., 1982, Stratigraphy, age, and tectonic setting of the Miocene- Pliocene lacustrine sediments of the western Snake River Plain, Oregon and Idaho, in Bonnichsen, Bill, and Breckenridge, R.M., eds., Cenozoic geology of Idaho: Idaho Bureau of Mines and Geology Bulletin 26, p. 559-578. [Also available at https://www.idahogeology.org/ product/b-26.]

Kjelstrom, L.C., 1995, Streamflow gains and losses in the Snake River and ground-water budgets for the Snake River Plain, Idaho and eastern Oregon: U.S. Geological Survey Professional Paper 1408-C, p. C1-C47; 1 plate in pocket. [Also available at https://doi.org/10.3133/ pp1408Chttps://doi.org/10.3133/pp1408C.]

Lawrence, D.C., 1988, Geologic field trip guide to the northern Succor Creek area, Malheur County, Oregon: Oregon Geology, v. 50, no. 2, p. 15-21. [Also available at https://www.oregongeology.org/pubs/OG/OGv50n02.pdf.].
Lewis, R.S., Link, P.K., Stanford, L.R., and Long, S.P., 2012, Geologic map of Idaho: Moscow, Idaho Geological Survey M-9, scale 1:750,000, 1 sheet, 18 p. booklet. [Also available at https://www.idahogeology.org/Products/reverselook.asp? switch=title\&value $=$ GeologicMapofIdaho.]

Lewis, R.S., Kiilsgaard, T.H., Bennett, E.H., and Hall, W.E., 1987, Lithologic and chemical characteristic of the central and southeastern part of the southern Idaho batholith, in Vallier, T.L., and Brooks, H.C., eds., Geology of the Blue Mountains region of Oregon, Idaho, and Washington: U.S. Geological Survey Professional Paper 1436, p. 171-196. [Also available at https://doi.org/10.3133/pp1436.].

Lewis, R.S., Link, P.K., Stanford, L.R., and Long, S.P., 2012, Geologic map of Idaho: Moscow, Idaho Geological Survey M-9, scale 1:750,000, 1 sheet, 18 p. booklet. [Also available at https://www.idahogeology.org/Products/reverselook.asp? switch $=$ title \&value $=$ GeologicMapofIdaho.]

Lewis, R.S., Phillips, W.M., Feeney, D.M., Schmidt, K.L., and Wood, S.H., 2016, Geologic map of the Montour Quadrangle, Boise and Gem Counties, Idaho: Moscow, Idaho Geological Survey DWM-177, scale 1:24,000, 1 sheet, accessed November 7, 2016, at https://www.idahogeology.org/Products/reverselook.asp? switch=title\&value=Geologic_Map_of_the_Montour Quadrangle,_Boise_and_Gem_Counties,_Idaho

Lindgren, J.E., 1982, Application of a ground water model to the Boise Valley aquifer in Idaho: Moscow, University of Idaho, M.S. thesis.

Lindgren, W., 1898, Boise folio, Idaho: U.S. Geological Survey Folios of the Geologic Atlas 45, 7 p., 4 plates. [Also available at https://doi.org/10.3133/gf45https://doi.org/ $10.3133 / \mathrm{gf} 45$.

Lindgren, W., and Drake, N.F., 1904a, Description of the Nampa Quadrangle, Idaho, Oregon: U.S. Geological Survey Folios of the Geologic Atlas 103, 5 p., 2 plates. [Also available at https://doi.org/10.3133/gf103https://doi.org/ 10.3133/gf103.]

Lindgren, W., and Drake, N.F., 1904b, Description of the Silver City Quadrangle, Idaho, Oregon: U.S. Geological Survey Folios of the Geologic Atlas 103, 6 p., 3 plates. [Also available at https://doi.org/10.3133/ gf104https://doi.org/10.3133/gf104.]

Lindholm, G.F., and Goodell, S.A., 1986, Irrigated acreage and other land uses on the Snake River Plain, Idaho and eastern Oregon: U.S. Geological Survey Hydrologic Atlas 691, 1 sheet. [Also available at https://doi.org/10.3133/ ha691https://doi.org/10.3133/ha691.] 
Lindholm, G.F., Garabedian, S.P., Newton, G.D., and Whitehead, R.L., 1982, Configuration of the water table, March 1980, in the Snake River plain regional aquifer system, Idaho and eastern Oregon: U.S. Geological Survey Open-File Report 82-1022, 1 sheet. [Also available at https://doi.org/10.3133/ofr821022https://doi.org/10.3133/ ofr821022.]

Lindholm, G.F., Garabedian, S.P., Newton, G.D., and Whitehead, R.L., 1988, Configuration of the water table and depth to water, spring 1980, water-level fluctuations, and water movement in the Snake River Plain Regional Aquifer System, Idaho and eastern Oregon: U.S. Geological Survey Hydrologic Atlas 703, 1 sheet. [Also available at https://doi.org/10.3133/ha703https://doi.org/ 10.3133/ha703.]

Lutgens, F.K., and Tarbuck, E.J., 1982, The Atmosphere 2nd ed.: Englewood Cliffs, New Jersey, Prentice-Hall, $478 \mathrm{p}$.

Malde, H.E., 1991, Quaternary geology and structural history of the Snake River Plain, Idaho and Oregon, in R. B. Morrison, ed., Quaternary nonglacial geology, conterminous U.S.: Geology of North America, Geological Society of America, v. K-2, p. 251-280.

Malde, H.E., and Powers, H.A., 1962, Upper Cenozoic stratigraphy of the western Snake River Plain, Idaho: Geological Society of America Bulletin, v. 73, no. 10, p. 1197-1220. [Also available at https://doi.org/10.1130/ 0016-7606(1962)73[1197:UCSOWS]2.0.CO;2.].

Maupin, M.A., 1991, Depth to water in the western Snake River Plain and surrounding tributary valleys, southwestern Idaho and eastern Oregon, calculated using water levels from 1980 to 1988: U.S. Geological Survey Water-Resources Investigations Report 91-4020, 1 sheet. [Also available at https://doi.org/10.3133/ wri914020https://doi.org/10.3133/wri914020.]

Mayo, A.L., Muller, A.B., and Mitchell, J.C., 1984, Geochemical and isotopic investigations of thermal water occurrences of the Boise Front Area, Ada County, Idaho: Boise, Idaho Department of Water Resources, Water Information Bulletin 30, part 14, 55 p. [Also available at http://www.idwr.idaho.gov/files/publications/wib30p14geothermal-boise-front-area.pdf.]

McGrath, C.L., Woods, A.J., Omernik, J.M., Bryce, S.A., Edmondson, M., Nesser, J.A., Shelden, J., Crawford, R.C., Comstock, J.A., and Plocher, M.D., 2002, Ecoregions of Idaho (2 sided color poster with map, descriptive text, summary tables, and photographs): U.S. Geological Survey, 1 sheet, scale 1:1,350,000. [Also available at https://archive.epa.gov/wed/ecoregions/web/html/ ideco.html\#Please\%20note.]
Mitchell, J.C., 1981, Geochemistry, Chapter 4, in Mitchell, J.C., ed., Geothermal investigations in Idaho, Part 11, Geological, hydrological, geochemical and geophysical investigations of the Nampa-Caldwell and adjacent area, Southwestern Idaho: Boise, Idaho Department of Water Resources Water Information Bulletin 30, Part 11, p. 43-78. [Also available at https://idwr.idaho.gov/files/publications/ wib30p11-geothermal-nampa-caldwell-areas.pdf.]

Mundorff, M.J., Crosthwaite, E.G., and Kilburn, C., 1964, Ground water for irrigation in the Snake River basin in Idaho: U.S. Geological Survey Water-Supply Paper 1654, 224 p. [Also available at https://doi.org/10.3133/wsp1654.].

National Climatic Data Center, 2019, CONUS Climate Divisions datasets, accessed May 29, 2019, at https://www1.ncdc.noaa.gov/pub/data/cirs/climdiv/

National Oceanic and Atmospheric Administration, 2019, Climate data online: National Oceanic and Atmospheric Administration database, accessed May 29, 2019, at https://www.ncdc.noaa.gov/cdo-web/

Nelson, L.B., Niemi, W.L., and Stoker, R.C., 1980, Geothermal resource exploration in Boise, Idaho: Idaho Falls, EG\&G Idaho, EGG-2011, prepared for the U.S. Department of Energy under contract DE-AC07-76IDO1570, 25 p. [Also available at https://www.osti.gov/geothermal/biblio/5598356geothermal-resource-exploration-boise-idaho.]

Newton, G.D., 1991, Geohydrology of the regional aquifer system, western Snake River plain, southwestern Idaho: U.S. Geological Survey Professional Paper 1408-G, 52 p., 1 plate in pocket. [Also available at https://doi.org/10.3133/ pp1408Ghttps://doi.org/10.3133/pp1408G.]

O'Connor, J.E., 1990, Hydrology, hydraulics, and sediment transport of Pleistocene Lake Bonneville flooding on the Snake River, Idaho: Tucson, University of Arizona, Ph.D. dissertation, 192 p., accessed October 31, 2018, at http://hdl.handle.net/10150/191159]

Othberg, K.L., 1994, Geology and geomorphology of the Boise Valley and adjoining areas, western Snake River Plain, Idaho: Idaho Geological Survey Bulletin 29, 54 p. [Also available at https://www.idahogeology.org/Products/ reverselook.asp?switch $=$ title\&value $=$ Geology_and Geomorphology_of_the_Boise_Valley_and_Adjoining _ Areas,_Western_Snake_River_Plain,_Idaho.]

Othberg, K.L., and Burnham, W.L., 1990, Geologic map of the Lucky Peak Quadrangle, Ada County, Idaho: Idaho Geological Survey Technical Report 90-4, scale 1:24000, 11 p., 1 pl. [Also available at https://www.idahogeology.org/ product/t-90-4.] 
Othberg, K.L., and Stanford, L.R., 1990, Geologic map of the Eagle Quadrangle, Ada County, Idaho: Idaho Geological Survey Technical Report 90-5, scale 1:24000, 7 p., 1 pl. [Also available at https://www.idahogeology.org/ product/t-90-5.]

Othberg, K.L., and Stanford, L.R., 1992, Geologic map of the Boise Valley and adjoining area, western Snake River Plain, Idaho: Idaho Geological Survey Geologic Map GM-18, 1 sheet, scale 1:100,000, accessed November 7,2016, at https://www.idahogeology.org/Products/reverselook.asp? switch=title\&value=Geologic_Map_of_the_Boise_Valley_ and_Adjoining_Area,_Western_Snake_River_Plain,_Idaho

Othberg, K.L., Stanford, L.R., and Burnham, W.L., 1990, Geologic map of the Cloverdale Quadrangle, Ada County, Idaho: Idaho Geological Survey Technical Report 90-6, scale 1:24000, 9 p., 1 pl. [Also available at https://www.idahogeology.org/product/t-90-6.]

Pacific Groundwater Group, 2008a, M3 Eagle Groundwater flow model and analysis of pumping impacts - first year progress report: Seattle, Washington.

Pacific Groundwater Group, 2008b, Model refinement and recalibration; re-simulation of 50-year drawdown; and assessment of effects of reduced canal leakage (M3 Eagle Groundwater flow model): memorandum to Hydro Logic, Inc., November 14, 2008, Seattle, Washington.

Perkins, M.E., Brown, F.H., and Nash, W.P., McIntosh, William, and Williams, S.K., 1998, Sequence, age, and source of silicic fallout tuffs in middle to late Miocene basins of the northern Basin and Range province: Geological Society of America Bulletin, v. 110, no. 3, p. 344-360. [Also available at https://doi.org/10.1130/ 0016-7606(1998)110\%3C0344:SAASOS\%3E2.3.CO; 2https://doi.org/10.1130/00167606(1998)110\%3C0344:SAASOS\%3E2.3.CO;2.]

Petrich, C.R., 2004a, Simulation of ground water flow in the lower Boise River Basin: Boise, University of Idaho, Idaho Water Resources Research Institute Research Report IWWRRI-2004-02, 130 p. [Also available at http://www.idwr.idaho.gov/files/projects/treasure-valley/ TVHP-Model.pdf.]

Petrich, C.R., 2004b, Treasure Valley Hydrologic Project executive summary: Moscow, University of Idaho Water Resources Research Institute, Research Report IWRRI-2004-04, 33 p. [Also available at http://www.idwr.idaho.gov/WaterInformation/Projects/tvhprevised/Reports/reports.htm.]
Petrich, C.R., and Urban, S.M., 2004c, Characterization of ground water flow in the lower Boise River basin: Moscow, University of Idaho Water Resources Research Institute, Research Report IWRRI-2004-01, 149 p. [Also available at http://www.idwr.idaho.gov/WaterInformation/Projects/tvhprevised/Reports/reports.htm.]

Phillips, W.M., Lewis, R.S., Gillerman, V.S., Garwood, D.L., and Stewart, D.E., 2012, Geologic Map of the Mayfield Area, Ada and Elmore Counties, Idaho; Idaho: Geological Survey Digital Web Map DWM-144, scale 1:36,000. [Also available at https://www.idahogeology.org/product/ dwm-144.]

Repenning, C.A., Weasma, T.R., and Scott, G.R., 1995, The early Pleistocene (latest Blancan-earliest Irvingtonian) Froman Ferry fauna and history of the Glenns Ferry Formation, southwestern ldaho: U.S. Geological Survey Bulletin 2105, 86 p. [Also available at https://doi.org/ 10.3133/b2105.].

Russell, I.C., 1902, Geology and water resources of the Snake River plains of Idaho: U.S. Geological Survey Bulletin 199, 192 p., 25 pl. [Also available at https://doi.org/10.3133/ b199https://doi.org/10.3133/b199.]

Russell, I.C., 1903a, Notes on the geology of southwestern Idaho and southeastern Oregon: U.S. Geological Survey Bulletin 217, 83 p., 18 pl. [Also available at https://doi.org/ 10.3133/b217https://doi.org/10.3133/b217.]

Russell, I.C., 1903b, Preliminary report on artesian basins in southwestern Idaho and southeastern Oregon: U.S. Geological Survey Water Supply Paper 78, 53 p., 2 pl. [Also available at https://doi.org/10.3133/wsp78https://doi.org/ 10.3133/wsp78.]

Water Engineering, S.P.F., 2004, Aquifer evaluation in the Big Gulch and Little Gulch areas of Spring Valley Ranch: Boise, Idaho, SPF Water Engineering, LLC, Report prepared for SunCor Development Company, 23 p., 6 apps. [Also available at http://www.idwr.idaho.gov/Browse/ WaterInfo/NAC/consultant_reports/Avimor/Aquifer $\% 20$ Evaluation\%2010_2004.pdf.]

Water Engineering, S.P.F., 2016, Treasure Valley DCMI water-demand projections (2015-2065): Boise, SPF Water Engineering, 131 p., 3 appendices. [Also available at http:/www.idwr.idaho.gov/files/publications/20160808OFR-Treasure-Valley-Water-Demand-(2015-2065).pdf.]

Savage, C.N., 1958, Geology and mineral resources of Ada and Canyon Counties: Moscow, Idaho Bureau of Mines and Geology County Report C-3, 111 p., 2 figs in pocket. [Also available at https://www.idahogeology.org/Products/ reverselook.asp?switch $=$ title\&value $=$ Geology_and Mineral_Resources_of_Ada_and_Canyon_Counties.] 
Savage, C.N., 1961, Geology and mineral resources of Gem and Payette Counties: Moscow, Idaho Bureau of Mines and Geology County Report C-4, 50 p., 2 figs in pocket. [Also available at https://www.idahogeology.org/Products/ reverselook.asp?switch $=$ title\&value $=$ Geology_and Mineral_Resources_of_Gem_and_Payette_Counties.]

Schmidt, R.D., 2008, Modeling drain interactions with shallow groundwater in the Boise Valley using analytic elements, prepared for the U.S. Bureau of Reclamation by RD Schmidt and Associates, Boise, Idaho.

Schmidt, R.D., Cook, Z., Dyke, D., Goyal, S., McGown, M., and Tarbet, K., 2008, Distributed parameter water budget data base for the lower Boise Valley-U.S. Bureau of Reclamation. Pacific Northwest Region, 109 p. [Also available at http://www.idwr.idaho.gov/WaterInformation/projects/ nac/Publications/PDFs/A_Distributed_Parameter_Water_ Budget_Data_Base_for_the_Lower.pdf.]

Smith, G.R., Morgan, N., and Gustafson, E., 2000, Fishes of the Pliocene Ringold Formation of Washington and history of the Columbia River drainage: University of Michigan Museum of Paleontology Papers on Paleontology, v. 32, 42 p. [Also available at https://deepblue.lib.umich.edu/handle/ 2027.42/48664.]

Spitz, K., and Moreno, J., 1996, A practical guide to groundwater and solute transport modeling: New York, John Wiley and Sons, $461 \mathrm{p}$.

Squires, E., Wood, S.H., and Osiensky, J.L., 1992, Hydrogeologic framework of the Boise aquifer system, Ada County, Idaho: Moscow, University of Idaho, Idaho Water Resources Research Institute Research Technical Completion Report 14-08-0001-G1559-06, reprinted with corrections, $75 \mathrm{p}$.

Squires, E., Utting, M., and Pearson, L., 2007, M3 Eagle regional hydrogeologic characterization, North Ada, Canyon, and Gem Counties, Idaho, year one progress report-May 4, 2007: Boise, Idaho, Hydro Logic, Inc., consultants' report, 31 p. [Also available at http://www.idwr.idaho.gov/Browse/WaterInfo/NAC/ consultant_reports/M3/M3\%20Eagle $\% 20$ Regional $\% 20$ Hydrogeologic $\% 20$ Characterization $\% 20$ Year $\% 20$ One $\% 20$ Progress\%20Report-\%20Final $\% 20 \% 20 \% 20-\% 20 J u l y \% 20$ 26-2007.pdf.]

Stacy, S.M., 1993, When the river rises-Flood control on the Boise River 1943-1985: Boulder, University of Colorado Program on Environment and Behavior Special Publication 27, $187 \mathrm{p}$.
Stevens, J.A., undated a, A history of the Pioneer Irrigation District, Idaho, an initial report, 1884-1938: Boise, Stevens historical Research Associates, consultant report, $63 \mathrm{p}$. [Also available at http://www.shraboise.com/docs/AHistory-of-the-Pioneer-Irrigation-District.pdf.]

Stevens, J.A., undated b, Water in the Boise Valley, a history of the Nampa and Meridian Irrigation District: Boise, Stevens Historical Research Associates, consultant report, 64 p. [Also available at http://www.shraboise.com/docs/ Water-in-the-Boise-Valley-NMID.pdf.]

North America, S.U.E.Z., 2019, About your water: Suez North America website, accessed May 29, 2019, at https://www.mysuezwater.com/idaho/water-in-my-area/ about-my-water

Sukow, J., 2012, Expansion of Treasure Valley Hydrologic Project groundwater model: Boise, Idaho Department of Water Resources, 34 p. [Also available at http://www.idwr.idaho.gov/water-data/projects/east-adacounty/references.html.].

Sukow, J., 2016, Evaluation of transient groundwater model of the Treasure Valley Aquifer (BOR, 2013) and recommendations for future work: Boise, Idaho Department of Water Resources, draft memorandum, $19 \mathrm{p}$.

Swirydczuk, K., Wilkison, B.H., and Smith, G.R., 1979, The Pliocene Glenns Ferry oolite; Lake-margin carbonate deposition in the southwestern Snake River Plain: Journal of Sedimentary Petrology, v. 49, p. 95-104. [Also available at https://doi.org/10.1306/212F789C-2B24-11D78648000102C1865D.].

Swirydczuk, K., Wilkison, B.H., and Smith, G.R., 1980, The Pliocene Glenns Ferry oolite-II-Sedimentology of oolitic limestone terrace deposits: Journal of Sedimentary Petrology, v. 50, no. 4, p. 1237-1248. [Also available at https://doi.org/10.1306/212F7B58-2B24-11D78648000102C1865D.].

Tesch, C., 2013, East Ada County comprehensive hydrologic investigation: Boise, Idaho Department of Water Resources Technical Report, 51 p., Also available at http://www.idwr.idaho.gov/files/publications/201310MISC-East-Ada-County-Comprehensive-HydrologicInvestigation.pdf]

Theis, C.V., Brown, R.H., and Meyer, R.R., 1963, Estimating the transmissibility of aquifers from the specific capacity of wells, in Bentall, Ray, ed., 1963, Methods of determining permeability, transmissibility and drawdown: U.S. Geological Survey Water-Supply Paper 1536-I, p. 331-341. [Also available at https://doi.org/10.3133/ wsp15361https://doi.org/10.3133/wsp15361.] 
Thomasson, H.G., Jr., Olmstead, F.H., and LeRoux, E.F., 1960, Geology, water resources and usable ground-water storage capacity of part of Solano County, California: U.S. Geological Survey Water-Supply Paper 1464, 693 p. 19 plates in pocket. [Also available at https://doi.org/10.3133/ wsp1464https://doi.org/10.3133/wsp1464.]

Thoma, M., 2008, Investigating recharge routes to the Treasure Valley Aquifer System, Idaho using noble gas thermometry: Boise, Boise State University M.S. Thesis, 400 p. [Also available at https://scholarworks.boisestate.edu/td/400/.].

U.S. Board on Geographic Names, 2019, U.S. Board on Geographic Names: U.S. Geological Survey website, accessed May 20, 2019, at https://www.usgs.gov/corescience-systems/ngp/board-on-geographic-names]

U.S. Bureau of Reclamation, 2019, AgriMet weather data: U.S. Bureau of Reclamation database, accessed July 23, 2019, at https://www.usbr.gov/pn/agrimet/wxdata.html

U.S. Census Bureau, 2019, American Fact Finder: U.S. Census Bureau database, accessed May 20, 2019, at https://factfinder.census.gov/faces/nav/jsf/pages/index.xhtml

U.S. Geological Survey Geologic Names Committee, 2018, Divisions of geologic time-Major chronostratigraphic and geochronologic units: U.S. Geological Survey Fact Sheet 2018-3054, 2 p. [Also available at https://doi.org/10.3133/ fs20183054https://doi.org/10.3133/fs20183054.]

U.S. Geological Survey, 2019a, 3D Elevation Program, About 3DEP Products \& Services: U.S. Geological Survey website, accessed May 20, 2019, at https://www.usgs.gov/core-science-systems/ngp/3dep/ about-3dep-products-services

U.S. Geological Survey, 2019b, National Water Information System: Web interface, accessed May 20, 2019, at https://dx.doi.org/10.5066/F7P55KJNhttps://dx.doi.org/ 10.5066/F7P55KJN.]

U.S. Geological Survey, 2019c, USGS 1:1,000,000-Scale Federal Lands of the United States 201412 Shapefile: U.S. Geological Survey website, accessed May 20, 2019, at https://www.sciencebase.gov/catalog/item/ 552d6eabe4b0b22a157f563c]

Urban, S.M., 2004, Water budget for the Treasure Valley aquifer system for the years 1996 and 2000: Moscow, University of Idaho Water Resources Research Institute, Research Report unnumbered, variously paged. [Also available at http://www.idwr.idaho.gov/WaterInformation/ Projects/tvhp-revised/Reports/reports.htm.]
Van Tassell, J., Ferns, M., McConnell, V., and Smith, G.R., 2001, The mid-Pliocene Imbler fish fossils, Grande Ronde Valley, Union County, Oregon, and the connection between Lake Idaho and the Columbia River: Oregon Geology, v. 63, no. 3, p. 77-96. [Also available at https://www.oregongeology.org/pubs/OG/OGv63n03.pdf.].

Waag, C.J., and Wood, S.H., 1987, Geothermal investigations in Idaho, part 16-1, Evaluation of the Boise geothermal system: Boise, Idaho Department of Water Resources, Water Information Bulletin 30, part 16-1, variously paged. [Also available at http://www.idwr.idaho.gov/files/publications/ wib30p16p1-geothermal-boise-system.pdf.]

Welhan, J.A., 2012, Preliminary hydrogeologic analysis of the Mayfield area, Ada and Elmore Counties, Idaho: February, $42 \mathrm{p}$. [Also available at http://www.idwr.idaho.gov/waterdata/projects/east-ada-county/references.html.]

Western Regional Climate Center, 2019, Idaho Climate Summaries: Western Regional Climate Center Web site, accessed May 29, 2019, at https://wrcc.dri.edu/summary/ climsmid.html

Wheeler, H.E., and Cook, E.F., 1954, Structural and stratigraphic significance of the Snake River capture, Idaho-Oregon: The Journal of Geology, v. 62, no. 6, p. 525-536. [Also available at https://www.journals.uchicago.edu/doi/pdfplus/10.1086/ 626205.].

Whitehead, R.L., 1986, Geohydrologic framework of the Snake River Plain, Idaho and eastern Oregon: U.S. Geological Survey Open-File Report 87-107, 60 p. [Also available at https://doi.org/10.3133/ofr87107.].

Whitehead, R.L., 1992, Geohydrologic framework of the Snake River Plain regional aquifer system, Idaho and eastern Oregon: U.S. Geological Survey Professional Paper 1408-B, 32 p., 6 plates in pocket. [Also available at https://doi.org/10.3133/pp1408Bhttps://doi.org/10.3133/ pp1408B.]

Wood, S.H., 1994, Seismic expression and significance of a lacustrine delta in Neogene deposits of the western Snake River Plain, Idaho: The American Association of Petroleum Geologists Bulletin, v. 78, no. 1, p. 102-121. [Also available at http://archives.datapages.com/data/bulletns/1994-96/ images/pg/00780001/0100/0102.pdf.].

Wood, S.H., 1997a, Structural contour map of the base of Quaternary basalt: Boise State University, Contribution to the Treasure Valley Hydrologic Project, 1 sheet, scale 1:100,000. [Also available at http://www.idwr.idaho.gov/ files/projects/treasure-valley/Murphy-MtHome-basaltmap.pdf.] 
Wood, S.H., 1997b, Structure contour map of top of the mudstone facies, western Snake River Plain, Idaho: Boise State University, Contribution to the Treasure Valley Hydrologic Project, 1 sheet, scale 1:100,000. [Also available at http://www.idwr.idaho.gov/files/projects/ treasure-valley/West-Snake-mudstone-facies-map.pdf.]

Wood, S.H., 2004, Geology across and under the Western Snake River Plain, Idaho-Owyhee Mountains to the Boise Foothills, in Haller, K.M., and Wood, S.H., eds., Geological field trips in southern Idaho, eastern Oregon, and northern Nevada: U.S. Geological Survey Open-File Report 2004-1222, p. 84-107. [Also available at https://pubs.usgs.gov/of/2004/1222/.].

Wood, S.H., and Anderson, J.E., 1981, Geology, Chapter 2, in Mitchell, J.C., ed., Geothermal investigations in Idaho, Part 11, Geological, hydrological, geochemical and geophysical investigations of the Nampa-Caldwell and adjacent area, Southwestern Idaho: Boise, Idaho Department of Water Resources Water Information Bulletin 30, Part 11, p. 9-32, 6 pl. [Also available at http://www.idwr.idaho.gov/ files/publications/wib30p11-geothermal-nampa-caldwellareas.pdf.]
Wood, S.H., and Burnham, W.L., 1983, Boise, Idaho geothermal system: Geothermal Resources Council Transactions, v. 7, p. 215-223.

Wood, S.H., and Clemens, D.M., 2002, Geologic and tectonic history of the western Snake River Plain, Oregon and Idaho, in Bonnichsen, B., White, C.M., and McCurry, M., (eds.), 2004, Tectonic and magmatic evolution of the Snake River Plain Volcanic Province: Moscow, Idaho Geological Survey Bulletin 30, p. 69-103. [Also available at https://www.idahogeology.org/Products/reverselook.asp? switch=title\&value=Tectonic_and_Magmatic_Evolution of_the_Snake_River_Plain_Volcanic_Province.]

Wood, S.H., Breedlovestrout, R., Lewis, R.S., Feeney, D.M., Isakson, V.H., and Schmitz, M.D., 2018, Inferred middle Miocene ages for reservoir rocks of western Snake River Plain production, Idaho (abs): American Association of Petroleum Geologists Annual Convention and Exhibition, Salt Lake City, May 20-23, 2018. [Also available at http://www.searchanddiscovery.com/abstracts/html/2018/ ace2018/abstracts/2856575.html.] 

Publishing support provided by the U.S. Geological Survey Science Publishing Network, Tacoma Publishing Service Center

For more information concerning the research in this report, contact the Director, Idaho Water Science Center

U.S. Geological Survey

230 Collins $\mathrm{Rd}$

Boise, Idaho 83702-4520

https://www.usgs.gov/centers/id-water 


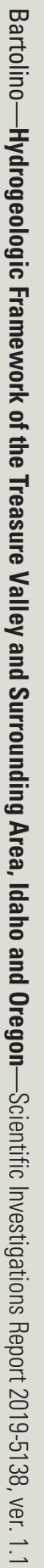

